*** WORKING PAPER ***

More Time with the Family? Workplace Flexibility Policies and Fathers' Time with Children

\author{
Dana Wray \\ University of Toronto \\ dana.wray@mail.utoronto.ca
}

September 9, 2021

Funding: This research is supported by a Social Sciences and Humanities Research Council Doctoral Fellowship and a University of Toronto Summer Program-Level Fellowship.

Acknowledgements: The author gratefully acknowledges Melissa Milkie and Irene Boeckmann for providing invaluable feedback, as well as Richard J. Petts for providing thoughtful comments on a version presented at the 2021 American Sociological Association's annual meeting. 


\title{
More Time with the Family? Workplace Flexibility Policies and Fathers' Time with Children
}

\author{
Abstract \\ Workplace flexibility policies, which provide control over the timing and location of work, are a \\ family-friendly resource that may facilitate increased father-child time. Yet, research on this \\ relationship often focuses narrowly on "childcare time," which not only overlooks the majority \\ of time fathers spend with their children, but also neglects fathers' accessibility to and \\ responsibility for children as well as the co-presence of the mother. This limits our understanding \\ of how flexibility policies might enhance family well-being and mitigate persistent gender \\ inequalities. Using the 2017-2018 American Time Use Survey Leave Module, this study \\ examines the relationship between flextime (control over start and end times) and flexplace \\ (working from home) policies and different-sex partnered fathers' time with children. Access to \\ and use of flexibility policies are associated with more family time with children - when the \\ mother is also present. This includes not only time in childcare but also other activities such as \\ meals as well as supervision or accessibility. However, there are no differences in fathers' solo \\ parenting time. Ultimately, these findings elucidate a more comprehensive picture of how \\ flexibility policies might shape father involvement, and complicate our understanding of the \\ consequences of flexibility for family well-being and gender inequality. \\ Keywords: Fatherhood; Parenting; Workplace flexibility; Working from home; Flexible \\ schedules; Work-family policy; Time use
}




\section{Introduction}

Despite increases in fathers' time with children over the past several decades, the division of care work continues to be unequal and highly gendered (Bianchi, Robinson, and Milkie 2006; Craig 2006). Further, even as women's labor force participation has risen sharply over this time, without comparable increases in public policy supports for caregiving, families face a "time squeeze" when managing work and family (Jacobs and Gerson 2004). Workplace flexibility policies are a potential resource that may facilitate parents' involvement with children by allowing them to have control over the timing and location of their work to reconcile conflicting work and family demands (Chung 2020a; Hill et al. 2008). Importantly, workplace flexibility has received renewed attention during the COVID-19 pandemic, as parents struggle with the exacerbated collision of work and family life, and as employers and employees alike signal a greater need for flexible work (e.g., Chung et al. 2021).

A growing body of research focuses on how workplace flexibility policies may facilitate fathers' involvement with their children, with positive implications for family well-being and gender inequality in care work. Fathers face competing norms of involved fatherhood and economic provision (Chung 2020a; Gerstel and Clawson 2018; Jacobs and Gerson 2004), resulting in heightened work-family conflict and feelings of time inadequacy with children (Aumann, Galinsky, and Matos 2011; Milkie, Nomaguchi, and Schieman 2019). Theoretically, flexibility policies may mitigate the time conflict of work and family roles to allow fathers to spend more time with children, and may expose fathers to the reality of the work needed in caring for children (e.g., Carlson, Petts, and Pepin 2021; Kim 2020). Yet, the literature on this relationship is divided. Some studies show that fathers spend more time with children when they have access to or use flexibility policies (e.g., Carlson et al. 2021; Kim 2020), but associations vary depending on the amount and types of time spent caring for children (e.g., Genadek and Hill 
2017). Other studies show no changes in father-child time (e.g., Baxter 2011; Davis et al. 2015; Kim 2020), potentially because fathers may use flexibility instead for paid work or personal reasons by choice or because of fear of stigma and penalties (Lott and Chung 2016; Williams, Blair-Loy, and Berdahl 2013).

A key limitation of most existing research on workplace flexibility and father-child time is that studies overlook how flexibility policies might shift fathers' accessibility to and responsibility for children (Lamb 2000). Flexibility policies might enable fathers to spend more time solo parenting - a measure which can capture their heightened responsibility (Budig and Folbre 2004; Mullan and Craig 2009). Alternatively, flexibility may be associated instead with shared "family" time when the mother is also present. This distinction of the co-presence of the mother is important: shared family time may yield benefits for family well-being (e.g., Shaw and Dawson 2001; Snyder 2007), but it may not represent fathers "stepping up" to solo responsibility in ways that temper gender inequalities in the care for children by freeing up mothers' time and energy (Craig 2006; Raley, Bianchi, and Wang 2012). Finally, considering the "total time" fathers spend with children - whether solo parenting or in family time - is important to capture time spent interacting with kids in activities like shared mealtimes or time spent accessible to or supervising children (Budig and Folbre 2004; Craig 2006; Wray et al. 2021). Considering a wider conceptualization of father involvement is thus critical for our understanding of how flexibility policies might alter family well-being and mitigate or further entrench gender inequalities through father-child time.

This study contributes new insights on how workplace flexibility polices may operate as a tool to reconcile work and family life by elucidating associated changes in father involvement in a more comprehensive way. Notably, this study extends previous research by considering a broader range of father involvement, including fathers' total time with children - including, but 
not limited to childcare activities - and whether father-child time is spent solo parenting or concentrated in shared "family time" when the mother is also present (Craig 2006; Folbre et al. 2005; Lamb 2000). I use nationally representative data from the 2017-2018 American Time Use Survey (ATUS) Leave and Job Flexibility Module to examine how workplace flexibility policies are associated with this expanded conceptualization of father-child time for different-sex partnered fathers with an own household child under 18. This recent ATUS data overcomes limitations of previous studies which used data that was not nationally representative; is outdated and does not reflect contemporary patterns of workplace flexibility or fathering norms; or does not have detailed measures of workplace flexibility (Carlson et al. 2021).

\section{Background}

According to scholars, employers, and policymakers alike, workplace flexibility policies are a key family-friendly initiative (Chung 2020a; Jacobs and Gerson 2004). Employee-led workplace flexibility is defined as "the ability of workers to make choices influencing when, where, and for how long they engage in work-related tasks" (Hill et al. 2008:152). Two popular policies are flextime, which allows employees to set their own start and end times for work schedules; and flexplace, where employees can govern their work location, most often working from home (alternatively called "work-from-home," teleworking, or telecommuting). Work-family benefits in the workplace such as flexibility may take on greater importance in the context of the United States, considered a laggard in cross-national terms when it comes to the provision of workfamily policy at the state level (Gornick and Meyers 2003; Jacobs and Gerson 2004). This may increasingly become the norm as the COVID-19 pandemic shifts the future of work (Chung et al. 2021).

Flexibility in the workplace is broadly desired by employees (Chung 2020a; Jacobs and Gerson 2004): In a 2018 study, 95 percent of women and 97 percent of men reported a need for 
work flexibility (Dean and Auerbach 2018). Yet, only 29 percent of wage and salary workers have access to flexplace and 57 percent have access to flextime (U.S. Bureau of Labor Statistics 2019). Men and socioeconomically advantaged workers are also more likely to have access to and be able to use flexibility policies (Gerstel and Clawson 2018).

\section{Flexibility in the Context of Fatherhood}

To understand how workplace flexibility policies might matter for family life, the context of contemporary parenting norms for fathers is key. Norms of "involved" or "nurturant" fatherhood set expectations for fathers to be involved in the daily care of and responsibility for their children (Borgkvist et al. 2020; Coltrane 2004). At the same time, fathers are still encouraged to be family breadwinners (Townsend 2002; Wall and Arnold 2007). Mothers, then, are still positioned as primary caregivers responsible for children and fathers are cast as secondary parents or 'helpers' (Christopher 2012; Hays 1996; Wall and Arnold 2007). As a result, fathers spend less time with children compared to mothers, a source of persistent gender inequality (Bianchi et al. 2006; Craig 2006). These conflicting demands also impact fathers' well-being: fathers report felt time deficits with children (Milkie et al. 2004, 2019; Nomaguchi, Milkie, and Bianchi 2005) and high levels of work-family conflict (Aumann et al. 2011).

Given this context of fathering, work-family policies are a potential institutional support that may alter the way that gender structures the division of work and caregiving for children (Risman 1998). Workplace flexibility policies are a desired work-family resource that may be particularly effective in facilitating involvement in children's daily lives without relinquishing their roles as economic providers. Indeed, fathers point to the inflexibility of employment as a primary barrier to their involvement at home (Townsend 2002). This flexibility may be a resource to mitigate time-based role conflict between work and family roles, particularly when time devoted to works makes meeting the demands of family difficult (Allen et al. 2013; 
Greenhaus and Beutell 1985; Kim 2020). Second, flexibility policies may also expose fathers to the daily realities of caregiving tasks and responsibilities that were previously invisible (Carlson et al. 2021; Kroska and Elman 2009; Wray 2020). As they develop additional parenting skills and routines, and establish confidence in their own capabilities for caregiving through this exposure, these policies may enable fathers to change their behaviours in care work over both the short- and longer-term (Rehel 2014). Thus, workplace flexibility policies have the potential to "undo" gendered patterns of caregiving and enhance well-being for families by facilitating fathers' caregiving time.

At the same time, fathers' access to or use of flexibility policies may not lead to changes in their contribution to caregiving for children at all. Although men are more likely to have access than women, they are less likely to make use of these policies (Chung 2020a; Gerstel and Clawson 2018). This may be due to flexibility stigma, where fathers face bias for using flexibility for family and care purposes (Coltrane et al. 2013; Rudman and Mescher 2013; Williams et al. 2013). ${ }^{1}$ If fathers $d o$ use flexibility policies, they may do so to adhere to ideal worker and economic provider expectations by allocating more time or priority to their careers (Gerstel and Clawson 2014; Lott and Chung 2016), or to tend to their own personal needs and leisure time (Powell and Craig 2015). In these ways, flexibility policies may not lead to increased time with children and may actually reproduce and reinforce traditional gendered divisions of care work (Gerstel and Clawson 2014).

${ }^{1}$ In contrast, Munsch (2016) suggests fathers may receive a "bonus" - but only for flexibility use that still allows them to maintain full-time work hours. 


\section{Flexibility and Father Involvement: Considering Mothers' Co-Presence}

When considering how policies might facilitate father involvement, it is critical to consider a comprehensive picture of how fathers contribute to care for children. A classic typology of father involvement introduced by Lamb (2000) identifies three dimensions: engagement - where fathers are directly interacting with children; accessibility - passive care for children, where fathers are available to or supervising children; and responsibility - where fathers attend to or anticipate children's needs and plan for or organize children's lives. How or what types of time fathers contribute are central to understanding how policies might intervene in gendered divisions of care work, just as much as how much or the quantity of time. Overlooking these different types of father involvement may ultimately underestimate or obscure fathers' contributions to care work.

The most common measure of father involvement is the time spent interacting directly with children, or what Lamb calls "engagement." This is most often operationalized as time spent in childcare activities - such as attending to children's basic needs like feeding or bathing, or their developmental needs like playing with or reading to them (Bianchi et al. 2006; Craig 2006). At the same time, the majority of fathers' daily time with children - especially older children - takes place outside of these childcare activities, such as fathers' leisure, meals or housework when children are present (Wray et al. 2021). This "total time" with children thus more clearly reveals how fathers might shift their time with children in response to flexibility in order to be more engaged, accessible to, or responsible for children.

In addition, the total time with children may capture time when fathers are accessible to children and are providing supervisory or "passive care" for children (Budig and Folbre 2004; Craig 2006; Mullan and Craig 2009). Flexibility policies may expose fathers to the need to supervise or be "on-call" for children, or may make them more attuned to being embedded in 
their daily lives more widely than would be captured in childcare activities. Thus, looking beyond simply childcare activities to the total time fathers spend with children is crucial for capturing a fuller picture of all of fathers' time with children, whether they are engaged with children or accessible to them.

Beyond the time fathers spend interacting with or supervising children, flexibility may shift fathers' responsibility for children. Previous research argues that fathers' assumption of responsibility for children is critical for gender inequality in parenting, as it remains a fundamental part of motherhood (Christopher 2012; Craig 2006). Solo parenting time with children - without the mother present - can be used as a measure of an aspect of responsibility (Raley et al. 2012; Wray 2020). ${ }^{2}$ Fathers' solo parenting time can free mothers of the constraints of caregiving to pursue their own paid work, leisure, or other activities (Craig 2006; Raley et al. 2012; Wilson and Prior 2010). Solo parenting is also qualitatively different from time mediated by the mother for fathers, and may develop caregiving competencies for men that shift their role from a helper-manager dynamic to more equitable co-parenting (Craig 2006; Rehel 2014; Wilson and Prior 2010). Fathers' access to or use of flexibility policies may lead to increased solo parenting time if they shed light on previously invisible caregiving responsibilities and if they develop fathers' own caregiving competencies and identities (Knoester, Petts, and Pragg 2019; Rehel 2014; Wray 2020).

Alternatively, flexibility may allow fathers to instead carve out more "family" time with children and the mother is also present. Time together can foster parents' well-being, reduce

\footnotetext{
2 The use of time-based measures to capture responsibility is a matter of debate. Doucet (2015) argues that parental responsibility(s) cannot be quantified due to their complexity and relationality that is not easily distilled into tasks. Others assert that solo parenting and the presence of children "with" parents can serve as a measure of aspects of parents' "responsibility time" (Budig and Folbre 2004; Mullan and Craig 2009).
} 
parents' stress, and lessen the intensity of caregiving (Dunatchik and Speight 2020; Folbre et al. 2005; Roeters and Gracia 2016). Family time can be perceived as "quality time" (Snyder 2007) and a part of being "good parents"; it can be important for children's development, enhances family communication and cohesion, and strengthens a sense of family (Shaw 2008; Shaw and Dawson 2001). However, when mothers are still present, fathers' time with children is not substituting for mothers' time, thus preserving some of the inequalities of the division of care work for children (Craig 2006; Raley et al. 2012). The dynamics of family time for responsibility are unclear. If mothers take on the normative role of primary parent, this may preserve a helpermanager dynamic in shared time; or, parents may be taking on "co-responsibility" for children and sharing the work of parenting. Further, even if the time is spent with the mother present, this time may still encourage fathers to be more involved with and responsible for children in the longer-term by exposing them to care work needs and by underlining the importance of time with children (Rehel 2014). As such, considering whether flexibility policies might facilitate solo parenting or family time is critical as this time may have differing implications for well-being and gender inequality.

\section{Previous Research on Flextime, Flexplace, and Father-Child Time}

Research on flextime generally finds no relationship with father-child time, including time in childcare activities (Genadek and Hill 2017; Noonan, Estes, and Glass 2007; Rapoport and Le Bourdais 2008), total time with children (Baxter 2011; Davis et al. 2015; Genadek and Hill 2017; Hill et al. 2013; Rapoport and Le Bourdais 2008), or how fathers distribute time with children across activities (Genadek and Hill 2017; Rapoport and Le Bourdais 2008). One exception is Kim (2020), who finds the availability of flexible schedules is linked to fathers' more frequent reports of doing "routine" childcare activities (e.g., feeding or bathing children). 
Evidence on flexplace and father-child time is mixed and varies depending on the types of father-child time examined. When looking specifically at childcare activities (or "engaged" time), Genadek and Hill (2017) show that fathers who work from home decrease time in childcare, whereas Kim (2020) finds no association with fathers' frequency of participating in these activities. In contrast, studies using recent data from the ATUS Leave Module show that working from home is associated with increased childcare time (Lyttelton, Zang, and Musick 2020), particularly routine childcare activities (i.e., basic care) which are typically done more by mothers (Carlson et al. 2021). Carlton and colleagues (2021) also find that more frequent working from home is associated with more routine childcare, but that the reasons for working from do not matter.

When looking beyond childcare activities to the total time fathers report spending with children, empirical evidence is once again divided. Studies using experimental data on workplace interventions (Hill et al. 2013) or older time diary data (Genadek and Hill 2017; Wight and Raley 2008) show no change in total father-child time, whereas Pabilonia and Vernon (2020) show increases in total time with children using recent ATUS Leave Module data. Beyond the quantity of total time, the types and timing of their activities with children might shift, as shown by research that finds changes in fathers' time in meals, travel, or social activities when children are also present (Genadek and Hill 2017; Rapoport and Le Bourdais 2008).

Thus, although there seem to be positive associations between some times of flexibility and some types of father-child time, the overall picture is unclear. This may be due to methodological and conceptual challenges faced by previous research, which this study addresses. First, given both shifting fathering norms and the growing interest in and prevalence of workplace flexibility, older survey data and non-representative experimental data may not reflect the current context. This may explain why studies using experimental data (e.g., Hill et al. 
2013) or time diary data from almost two decades ago or more (Genadek and Hill 2017;

Rapoport and Le Bourdais 2008) may find different trends in father-child time. Second, studies which use single-item measures for flexibility may overlook important variation by access versus use, as well as reasons and frequency for flexibility. For example, Carlson and colleagues (2021) find that more frequent flexplace use is associated with more routine childcare time. Finally, previous research generally does not consider how fathers and mothers might be co-present during all time together with children, limiting our understanding of fathers' involvement in accessibility and responsibility for children.

This study thus extends existing research by asking: How are flextime and flexplace policies associated with fathers" solo and "family" (i.e., with the mother) childcare time and total time with children? Using the 2017-2018 ATUS Leave Module provides recent, nationally representative data; multiple measures of the frequency and reasons for access and use of flexibility; and detailed time diary data that can capture a more comprehensive picture of father involvement.

\section{Data and Methods}

\section{Data}

This study uses data from the American Time Use Survey in 2017 and 2018, which included supplemental information from the Leave and Job Flexibilities Module (Hofferth et al. 2020). ATUS time diaries ask respondents to recall their primary activities and who else was present over a 24-hour period, beginning at 4 a.m. the previous day. The Leave Module links this to information about workers' access to and use of workplace flexibility. To be eligible, respondents had to be employed wage and salary workers (not including self-employed workers) who completed the time diary. The full sample of the ATUS Leave Module is 10,071 respondents. I restrict the sample to men (5,132 cases dropped) who have at least one own 
household child under age 18 (2,871 cases dropped) and who have a partner (spouse or unmarried partner) present (179 cases dropped) who is different sex ( 2 cases dropped), resulting in a final sample of 1,882 different-sex partnered fathers with an own household child under 18 .

\section{Measures}

\section{Dependent Variables}

Total time with children is the daily minutes that a father reports being co-present "in the room with" or accompanying at least one own household child under age 18. I also show differences in total time with children by fathers' activity when children are present, including: childcare (see below); leisure activities (e.g., watching TV, talking, playing sports); meals at home and elsewhere; housework (e.g., cleaning, doing laundry, grocery shopping); and other activities (including time in paid work, education, caring for adults, or missing activities) (Bianchi et al. 2006). I also look separately at childcare time, or the daily minutes that a father reports caring for an own household child(ren) under age 18 as a primary activity. Childcare time includes activities such as basic or physical care, play activities, educational activities such as reading or helping with homework, and management activities such as attending events with or for children.

For both total time with children and the sub-category of childcare time, I consider the co-presence of the mother: (1) all childcare and total time with children, where there are no restrictions placed on presence of the mother; (2) family childcare and total time with children, where the mother (i.e., spouse/partner of the father) is present; and (3) solo childcare and total time with children, where the mother is not present.

\section{Independent Variables}

There are two focal independent variables related to access to "flextime." Access to flextime work measures whether respondents have flexible hours that allow them to vary or make 
changes in the times they begin and end work (yes $=1$, no $=0) .{ }^{3}$ The frequency of flextime work measures whether fathers can change the times they begin and end work rarely, occasionally, or on a frequent basis.

Flexplace use is a binary measure that captures whether fathers report full workdays only at home at least sometimes $(=1)$ or never working for full workdays at home $(=0) .{ }^{4}$ Reason why uses flexplace is measured as: no flexplace use $(=0)$; family reasons ("coordinate work schedule with personal or family needs"); work reasons ("finish or catch up on work," "job requires working from home", and "reduce commuting time or expense"); and other reasons ("personal preference," "weather," and "other"). Frequency of flexplace use measures whether fathers work from home less than monthly; at least monthly (once a month and once every 2 weeks); and at least once per week (at least once a week, 1 to 2 days, 3 to 4 days, and 5 or more days).

\section{Covariates}

Covariates that may be linked to fathers' time with children and their access to and use of flexibility policies include: educational attainment (less than high school=reference, high school graduate, some college, college graduate); father's employment status (part-time, under 35 hours=reference; full-time, 35-50 hours; overwork, 50+ hours); whether fathers report working on the diary day (at least one minute in paid work activities $=1$ ); spouse's employment status (not employed=reference, part-time employed, full-time employed); professional occupation

\footnotetext{
3 The ATUS Leave Module does not provide information on the use of flextime, only access to this policy.

${ }^{4}$ Fathers are asked whether they have access to flexplace; whether they ever use it; and whether there are workdays they work only at home at least sometimes - the latter is used to define flexplace use for several reasons. First, it follows recent work using the ATUS Leave Module (e.g., Carlson, Petts, and Pepin 2021; Pabilonia and Vernon 2020). Second, $88 \%$ of fathers with access to flexplace also report "ever" using it; $61 \%$ of those who "ever" use it report working from home for full workdays at least sometimes. Third, this definition excludes fathers who only ever take work home at the end of the day.
} 
$(=1)$; cohabiting $(=1)$ or married; race (white=reference, Black, Latinx, and other); family income $(<\$ 25,000=$ reference); the number of own household children under 18 ; the age of the youngest own household child (0-5 years old=reference, 6-12 years, 13-17 years); and whether the diary is a weekend (=1), holiday (=1), or summer month (July and August=1). For flextime policies, I control for whether access to flextime is a "formal, written program or policy offered by your employer" (=1) or an "informal arrangement"; and whether respondents without flextime access had input on times they begin and end work (=1). For flexplace models, I control for whether fathers have access to flexplace policies $(=1)$ even if they do not report using flexplace.

\section{Analytic Strategy}

First, I describe the characteristics of the samples of fathers with and without access to flextime and fathers who use or do not use flexplace, respectively. Second, I estimate ordinaryleast-squares (OLS) regression models for the association between father-child time and flexibility policies. Models are run for each different measure of father-child time and for flextime and flexplace measure separately, resulting in 30 different models presented as abridged results (full results available in the appendix). All analyses are weighted using respondent and replicate weights.

\section{Results}

Table 1 presents the characteristics of fathers with versus without access to flextime policies. Over half of all fathers (57.4 percent) reported having access to flextime, i.e., having flexible work hours that allow them to vary or change their work start and end times. Out of fathers with access, most report being able to change the times they begin and end work frequently (43 percent) or occasionally (38 percent). Flextime is an informal arrangement rather than a formal policy or program for most (76 percent) fathers with access. 
Table 1: Summary statistics by access to flextime

\begin{tabular}{|c|c|c|c|}
\hline & All fathers & $\begin{array}{l}\text { No access } \\
\text { to flextime }\end{array}$ & $\begin{array}{l}\text { Access } \\
\text { to flextime }\end{array}$ \\
\hline$N$ & 1,882 & 732 & 1,150 \\
\hline Flextime access & .57 & -- & -- \\
\hline \multicolumn{4}{|l|}{ Frequency of flextime access } \\
\hline Rarely & -- & -- & .19 \\
\hline Occasionally & -- & -- & .38 \\
\hline Frequent basis & -- & -- & .43 \\
\hline Flextime is formal policy & -- & -- & .24 \\
\hline Schedule input & .06 & .15 & -- \\
\hline \multicolumn{4}{|l|}{ Usual paid work hours } \\
\hline Part-time (<35 hours) & .03 & .04 & .03 \\
\hline Full-time (35-50 hours) & .68 & .70 & .66 \\
\hline Overwork (50+ hours) & .29 & .26 & .31 \\
\hline Worked on diary day* & .73 & .70 & .76 \\
\hline \multicolumn{4}{|l|}{ Educational attainment* } \\
\hline Less than high school & .07 & .12 & .04 \\
\hline High school graduate & .28 & .39 & .19 \\
\hline Some college & .21 & .22 & .20 \\
\hline College graduate & .45 & .28 & .57 \\
\hline Professional occupation* & .45 & .27 & .59 \\
\hline \multicolumn{4}{|l|}{ Spouse's employment status } \\
\hline Non-employed & .32 & .34 & .31 \\
\hline Part-time & .18 & .18 & .19 \\
\hline Full-time & .49 & .48 & .51 \\
\hline \multicolumn{4}{|l|}{ Family income* } \\
\hline Under $\$ 25 \mathrm{k}$ & .06 & .07 & .05 \\
\hline$\$ 25 \mathrm{k}$ to $\$ 50 \mathrm{k}$ & .17 & .24 & .11 \\
\hline$\$ 50 \mathrm{k}$ to $\$ 75 \mathrm{k}$ & .18 & .22 & .15 \\
\hline$\$ 75 \mathrm{k}$ to $\$ 100 \mathrm{k}$ & .19 & .19 & .19 \\
\hline$\$ 100 \mathrm{k}+$ & .40 & .28 & .49 \\
\hline \multicolumn{4}{|l|}{ Race* } \\
\hline White & .65 & .61 & .68 \\
\hline Black & .08 & .10 & .07 \\
\hline Latinx & .18 & .24 & .14 \\
\hline Other & .09 & .06 & .11 \\
\hline Age* $^{*}$ & 40.32 & 39.64 & 40.83 \\
\hline Cohabiting & .07 & .08 & .06 \\
\hline \multicolumn{4}{|l|}{ Age of youngest child } \\
\hline $0-5$ years old & .46 & .47 & .46 \\
\hline $6-12$ years old & .34 & .33 & .35 \\
\hline 13-17 years old & .19 & .20 & .19 \\
\hline Number of own HH kids under 18 & 1.88 & 1.90 & 1.86 \\
\hline
\end{tabular}

Note: ATUS 2017-2018 Leave Module. Total N=1,882. Means are weighted using respondent and replicate weights. $* \mathrm{p}<0.05$ (fathers with access to flextime vs. no access to flextime)

Table 2 presents the characteristics of fathers who use flexplace (fathers who report working only from home for an entire workday at least sometimes) and those who do not. 22 percent of those who do not use flexplace have access to flexplace policies, and 17 percent report 
ever working from home (but never for full workdays). The most common reason for working from home varies substantially across fathers is work-related concerns (45 percent). ${ }^{5}$ Another 29 percent of fathers state that family reasons drive their flexplace decisions. Further, fathers report using flexplace more frequently, with just under half working from home at least once per week and a third at least monthly.

As shown in Tables 1 and 2, fathers with access to flextime and who use flexplace are socioeconomically privileged (Gerstel and Clawson 2018). Like fathers with access to flextime policies, fathers who use flexplace are of higher socioeconomic status. They are much more likely to be college graduates and are disproportionately in professional occupations; they also have higher incomes and are more likely to be white.

Table 2: Summary statistics by use of flexplace ${ }^{1}$

\begin{tabular}{lccc}
\hline & All fathers & No flexplace use & Flexplace use \\
\hline$N$ & 1,882 & 1,438 & 444 \\
Able to work from home & .38 & .22 & -- \\
Ever work from home & .33 & .17 & -- \\
Flexplace use (full workdays at home) & .20 & -- & -- \\
Main reason for working from home & & & .29 \\
$\quad$ Family reasons & -- & -- & .45 \\
$\quad$ Work reasons & -- & -- & .26 \\
$\quad$ Other reasons & -- & -- & .23 \\
Frequency of working from home & & & .31 \\
$\quad$ Less than monthly & -- & -- & .46 \\
$\quad$ At least monthly & -- & -- & .02 \\
$\quad$ At least once a week & -- & -- & .66 \\
Usual paid work hours & & & .32 \\
$\quad$ Part-time (<35 hours) & .03 & .04 & .79 \\
Full-time (35-50 hours) & .68 & .68 & \\
Overwork (50+ hours) & .29 & .28 & .00 \\
Worked on diary day* & .73 & .72 & .07 \\
Respondent's educational attainment* & & & .12 \\
$\quad$ Less than high school & .07 & .09 & .81 \\
$\quad$ High school graduate & .28 & .33 & \\
Some college & .21 & .23 & .35 \\
College graduate & .45 & & \\
& & &
\end{tabular}

${ }^{5}$ Out of this 45 percent of fathers, about one-third each report they do so to finish or catch up on work or that their job requires working at home, respectively, whereas 28 percent point to reducing commuting time or expense. 


\begin{tabular}{lccc}
\hline & All fathers & No flexplace use & Flexplace use \\
\hline Professional occupation* & .45 & .36 & .82 \\
Spouse's employment status* & & & \\
$\quad$ Non-employed & .32 & .34 & .28 \\
Part-time & .18 & .17 & .23 \\
Full-time & .49 & .49 & .50 \\
Family income* & & & \\
$\quad$ Under \$25k & .06 & .07 & .01 \\
\$25k to \$50k & .17 & .20 & .03 \\
\$50k to \$75k & .18 & .19 & .14 \\
\$75k to \$100k & .19 & .20 & .15 \\
\$100k+ & .40 & .33 & .67 \\
Race* & & & .78 \\
White & .65 & .62 & .06 \\
Black & .08 & .09 & .04 \\
Latinx & .18 & .22 & .12 \\
Other & .09 & .08 & 42.19 \\
Age* & 40.32 & 39.85 & .02 \\
Cohabiting* & .07 & .08 & .44 \\
Age of youngest child & & & .34 \\
0-5 years old & .46 & .47 & .22 \\
6-12 years old & .34 & .34 & 1.86 \\
13-17 years old & .19 & .18 & 1.88 \\
Number of own HH kids under 18 & 1.88 & & \\
\hline
\end{tabular}

Note: ATUS 2017-2018 Leave Module. Total N=1,882. Means are weighted using respondent and replicate weights. $* \mathrm{p}<0.05$ (fathers who use flexplace vs. fathers who do not use flexplace).

Is flextime access associated with father-child time? Table 3 presents abridged OLS regression estimates for access to flextime policies (Panel A) and the frequency of flextime access (Panel B). Fathers who have access to flextime - flexible hours that allow them to change the times they start and end work - spend about 7.5 daily minutes more in family childcare activities with the mother present, all else held constant. Additionally, father-child time - in particular, "family" time - is dependent on the frequency of flextime access. Fathers who report having access to flextime on a frequent basis spend about 11 additional minutes daily in family childcare, when their spouse is also present, holding all else constant. In contrast, fathers who report "rarely" having access to flextime work spend 40 daily minutes less in all total time with 
children, holding all else constant. The majority of this difference (about 28 minutes per day) is concentrated in family total time with children, where the mother is also present. ${ }^{6}$

Table 3: OLS regression estimates for flextime and fathers' time with children

\begin{tabular}{llllllll}
\hline & \multicolumn{3}{c}{ Total time with children } & & \multicolumn{3}{c}{ Childcare time } \\
\cline { 2 - 6 } & All & Family & Solo & & All & Family & Solo \\
\hline Panel A: Flextime access & & & & & & \\
Flextime access & -1.22 & 6.18 & -7.40 & 4.27 & $7.46^{*}$ & -3.18 \\
& $(12.146)$ & $(10.652)$ & $(8.411)$ & $(5.711)$ & $(3.710)$ & $(4.475)$
\end{tabular}

\section{Panel B: Frequency of flextime access}

Frequency of flextime (ref. $=$ no flextime access)

\begin{tabular}{lllllll} 
Rarely & $-40.30 *$ & $-28.22 *$ & -12.08 & -3.97 & 6.36 & -10.33 \\
Occasionally & $(16.796)$ & $(15.200)$ & $(10.354)$ & $(8.246)$ & $(6.034)$ & $(5.447)$ \\
& 8.37 & 11.19 & -2.82 & 1.63 & 3.06 & -1.43 \\
Frequent basis & $(14.545)$ & $(12.138)$ & $(10.355)$ & $(6.695)$ & $(3.770)$ & $(5.725)$ \\
& 9.03 & 17.64 & -8.61 & 9.73 & $11.04 *$ & -1.31 \\
& $(14.188)$ & $(12.797)$ & $(9.705)$ & $(6.616)$ & $(4.698)$ & $(4.780)$ \\
\hline
\end{tabular}

Source: ATUS 2017 and 2018 Leave Module. Total $N=1,882$. All estimates weighted using respondent and replicate weights. Includes controls for: whether flextime is formal policy, schedule input, usual work hours (categorical), worked on diary day, educational attainment, spouse's employment status, family income, race, age, cohabiting, age of youngest child, number of own household kids under 18; and weekend, holiday, or summer diary. Full models available in appendix Tables A.1 and A.2. * $\mathrm{p}<0.05, * * \mathrm{p}<0.01, * * * \mathrm{p}<0.001$

What does this decrease in total family time with children look like in the daily lives of fathers who report "rarely" having access to flextime? Figure 1 shows predicted total family time with children across activities. Fathers who report "rarely" having access to flextime spend significantly less family total time with children in leisure and housework activities when children and their spouse or partner is present. These "rarely" fathers spend about 1 hour per day in leisure activities when their child(ren) and the mother are present, about 22 daily minutes less than fathers without flextime access who spend almost 1.4 hours in leisure with family. They

\footnotetext{
${ }^{6}$ This is statistically significant $(\mathrm{p}<0.05)$ in comparison with fathers without flextime access as well as those with occasional and frequent access.
} 
also spend about 10 daily minutes less in housework when their family is present -20 minutes daily, compared to 30 minutes for fathers with no flextime access.

Figure 1. Predicted Daily Minutes of "Family Time" in Activities, by Frequency of Access to Flextime (No Access vs. Rarely)

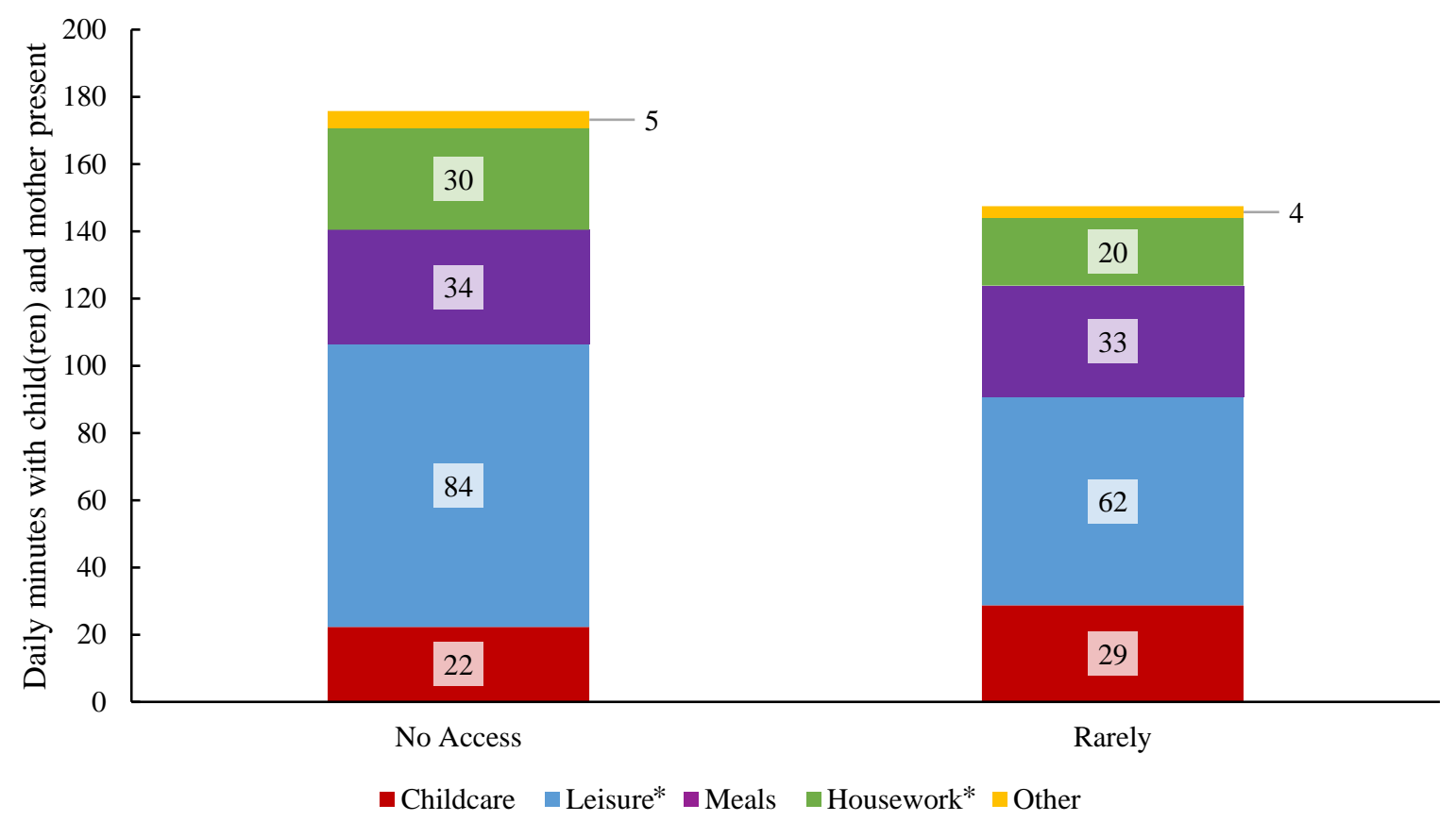

Source: ATUS 2017 and 2018 Leave Module. $N=918$. Predicted values calculated based on OLS models with all covariates and controls included (see appendix Table A.1). All estimates weighted using respondent and replicate weights. "Other" activities include: adult care, education, market work, and missing activities. * p $<0.05$.

Turning to flexplace policies, Table 4 presents abridged OLS regression estimates for whether fathers use flexplace (Panel A); reasons for flexplace use (Panel B); and the frequency of flexplace use (Panel C). Fathers who use flexplace report spending about 14 minutes more per day in childcare, the majority of which takes place with children and the mother present. Fathers spend almost 10 additional minutes daily in family childcare, all else held constant. This increase in childcare time depends on both the reasons for and the frequency of working from home. Fathers who report working from home for "family reasons" or for "other reasons" (e.g., personal preference, weather) also report about 12 and 14 daily minutes more in family childcare, respectively. In addition, fathers who report working from home at least once per 
week or more report spending 17 minutes more in all childcare, 14 daily minutes of which is in family childcare, when all else is held constant.

Table 4: OLS regression estimates for flexplace and fathers' time with children

\begin{tabular}{|c|c|c|c|c|c|c|}
\hline & \multicolumn{3}{|c|}{ Total time with children } & \multicolumn{3}{|c|}{$\underline{\text { Childcare time }}$} \\
\hline & All & Family & Solo & All & Family & Solo \\
\hline \multicolumn{7}{|c|}{ Panel A: Working from home } \\
\hline Flexplace use & $\begin{array}{l}46.45 * \\
(19.003)\end{array}$ & $\begin{array}{l}53.40 * * * \\
(15.285)\end{array}$ & $\begin{array}{l}-6.95 \\
(12.932)\end{array}$ & $\begin{array}{l}14.26^{*} \\
(5.960)\end{array}$ & $\begin{array}{l}9.71 * \\
(3.953)\end{array}$ & $\begin{array}{l}4.56 \\
(4.819)\end{array}$ \\
\hline \multicolumn{7}{|c|}{ Panel B: Reasons for flexplace use } \\
\hline \multicolumn{7}{|c|}{ Reasons for flexplace use (ref. = no flexplace use) } \\
\hline Family reasons & $\begin{array}{l}48.11 \\
(25.954)\end{array}$ & $\begin{array}{l}47.36^{*} \\
(20.895)\end{array}$ & $\begin{array}{l}0.74 \\
(20.056)\end{array}$ & $\begin{array}{l}20.42 \\
(10.802)\end{array}$ & $\begin{array}{l}11.64 * \\
(5.792)\end{array}$ & $\begin{array}{l}8.78 \\
(9.383)\end{array}$ \\
\hline Work reasons & $\begin{array}{l}54.23 * \\
(21.428)\end{array}$ & $\begin{array}{l}56.16 * * \\
(17.396)\end{array}$ & $\begin{array}{l}-1.93 \\
(15.008)\end{array}$ & $\begin{array}{l}11.24 \\
(8.350)\end{array}$ & $\begin{array}{l}5.77 \\
(5.152)\end{array}$ & $\begin{array}{l}5.47 \\
(7.212)\end{array}$ \\
\hline Other reasons & $\begin{array}{l}26.81 \\
(25.443)\end{array}$ & $\begin{array}{l}49.53 * \\
(22.150)\end{array}$ & $\begin{array}{l}-22.71 \\
(14.266)\end{array}$ & $\begin{array}{l}12.75 \\
(7.955)\end{array}$ & $\begin{array}{l}14.34 * \\
(6.441)\end{array}$ & $\begin{array}{l}-1.59 \\
(5.370)\end{array}$ \\
\hline \multicolumn{7}{|c|}{ Panel C: Frequency of flexplace use } \\
\hline \multicolumn{7}{|c|}{ Frequency of flexplace use (ref. = no flexplace use) } \\
\hline Less than monthly & $\begin{array}{l}12.67 \\
(26.729)\end{array}$ & $\begin{array}{l}18.74 \\
(19.559)\end{array}$ & $\begin{array}{l}-6.07 \\
(19.348)\end{array}$ & $\begin{array}{l}16.44 \\
(10.767)\end{array}$ & $\begin{array}{l}11.50 \\
(7.629)\end{array}$ & $\begin{array}{l}4.94 \\
(8.639)\end{array}$ \\
\hline At least monthly & $\begin{array}{l}57.22 * \\
(23.459)\end{array}$ & $\begin{array}{l}52.76^{* * *} \\
(19.043)\end{array}$ & $\begin{array}{l}4.47 \\
(17.619)\end{array}$ & $\begin{array}{l}7.35 \\
(9.944)\end{array}$ & $\begin{array}{l}1.21 \\
(5.220)\end{array}$ & $\begin{array}{l}6.14 \\
(8.840)\end{array}$ \\
\hline At least weekly & $\begin{array}{l}60.96^{* *} \\
(21.763)\end{array}$ & $\begin{array}{l}74.70 * * * \\
(18.831)\end{array}$ & $\begin{array}{l}-13.73 \\
(13.978)\end{array}$ & $\begin{array}{l}17.15^{*} \\
(7.663)\end{array}$ & $\begin{array}{l}13.79 * * \\
(4.801)\end{array}$ & $\begin{array}{l}3.36 \\
(6.305)\end{array}$ \\
\hline
\end{tabular}

Source: ATUS 2017 and 2018 Leave Module. Total $N=1,882$. All estimates weighted using respondent and replicate weights. In all cases, the reference group is never working only from home for full workdays. Includes controls for: flexplace access, usual work hours (categorical), worked on diary day, educational attainment, spouse's employment status, family income, race, age, cohabiting, age of youngest child, number of own household kids under 18; and whether the diary was on a weekend, holiday diary, or in the summer. Full models available in appendix Tables A.3, A.4, and A.5. * $\mathrm{p}<0.05, * * \mathrm{p}<0.01, * * * \mathrm{p}<0.001$

Fathers' use of flexplace policy also impacts their family total time with children with children. Those who use flexplace report spending about 53 additional daily minutes in time with children and their spouse present, in activities that include but are not limited to childcare. Fathers' total time with children does not seem to depend on reasons for working from home, with increased family total time with children regardless of reason. Finally, changes in time also depend on the frequency of working from home. Fathers who work at least monthly report 53 
additional daily minutes in family total time with children, and those who work at least weekly report 75 daily minutes in family total time with children.

Figure 2. Predicted Daily Minutes of "Family Time" in Activities, by Use of Flexplace

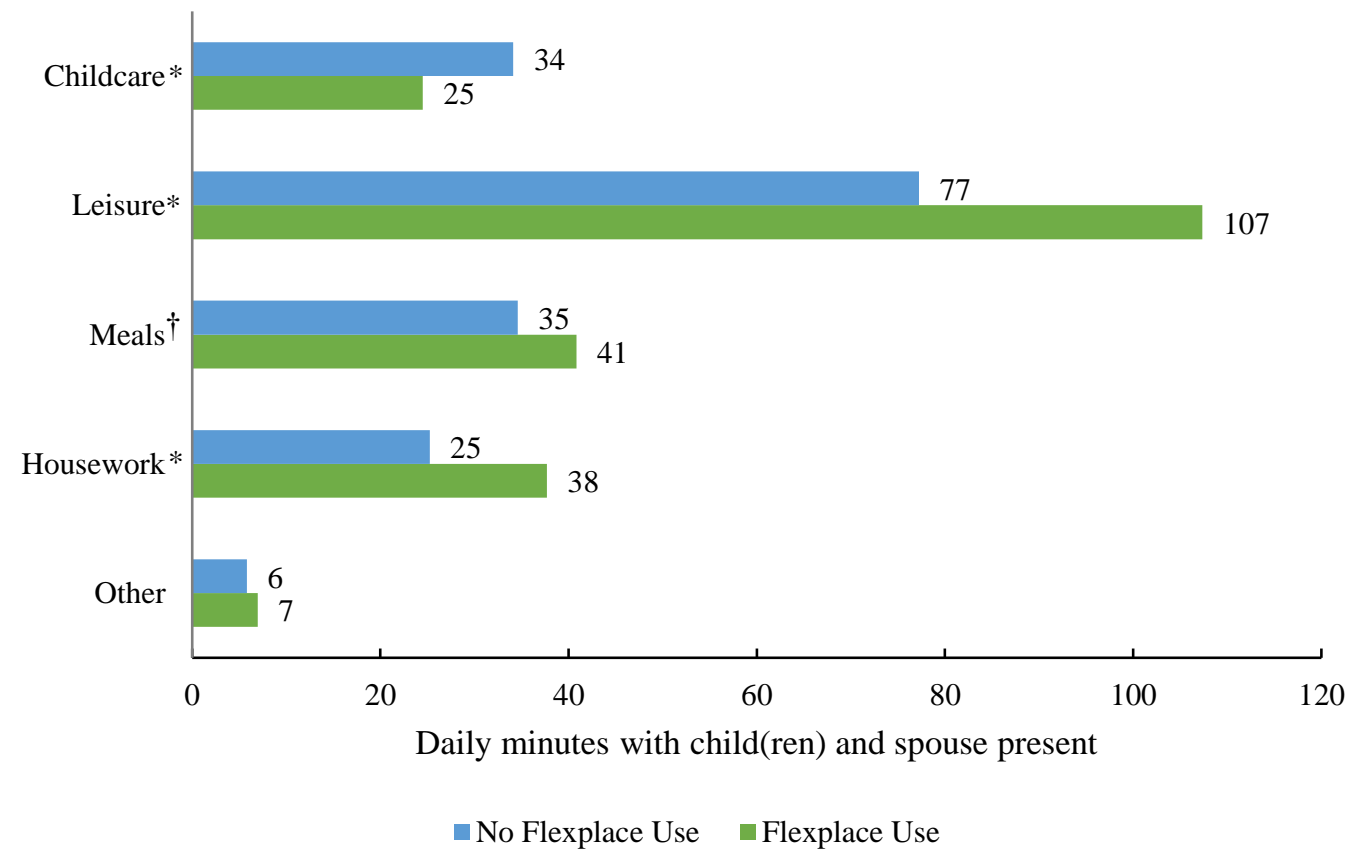

Source: ATUS 2017 and 2018 Leave Module. Total N=1,882. Predicted values calculated based on OLS models with all covariates and controls included (see appendix Table A.3). All estimates weighted using respondent and replicate weights. "Other" activities include: adult care, education, market work, and missing activities. ${ }^{*} \mathrm{p}<0.05, \dagger$ $\mathrm{p}<0.10$.

How do fathers who use flexplace spend family total time with children? Figure 2 shows the predicted daily minutes in total family time with children across activities. Compared to fathers who do not use flexplace, those who use flexplace policies spend significantly more family time with their child(ren) and partner across a wide range of activities, including childcare, leisure, and housework. ${ }^{7}$ Strikingly, fathers who use flexplace spend 30 daily minutes more in leisure activities with their children and the mother, and 13 minutes more in housework activities with family present.

${ }^{7}$ The 6-minute difference in family meals is marginally significant $(\mathrm{p}=0.09)$. 


\section{Discussion}

This study uses time diary data from the 2017-2018 ATUS Leave Module to investigate how workplace flexibility policies - flextime and flexplace - are associated with fathers' time with children. The association between workplace flexibility policies and fathers' time is contingent not only on the details of the policies, but also differs depending on the types of father-child time and the co-presence of the mother. Ultimately, flexibility policies are associated primarily with fathers" "family time" - time when not only children but also the mother is also present. These findings challenge our previous knowledge of how these policies might facilitate fathers' contributions to care work and complicate implications for gender inequality.

Flexplace use, or working from home, is linked to increased family time - especially when fathers work from home frequently - but no change in solo parenting time. Fathers who use flexplace report nearly an hour more per day (or about six hours per week more) with their child(ren) and the mother present. This difference is not only due to increased time in childcare (e.g., Carlson et al. 2021; Lyttelton et al. 2020) but also in other activities such as in leisure and housework activities with family present as well as family mealtimes (Genadek and Hill 2017; Rapoport and Le Bourdais 2008; Wight and Raley 2008). Importantly, this increase is not due to simply being in the same location as family while working at home (Powell and Craig 2015). Fathers who work from home, then, appear to be more involved in the daily lives of their children and families, but do not take on additional solo parenting responsibilities.

Fathers who have access to flextime, particularly those who can more frequently change their start and end times, report more family childcare time. However, there are few other associations. Fathers may use flextime to fit their work responsibilities around prioritized family activities (or vice versa), leading to shifts in the timing or quality of activities as well as reduced stress - but not more time (Baxter 2011; Genadek and Hill 2017; Hsin and Felfe 2014). 
Alternatively, fathers may use flextime for work-related purposes or personal time (Gerstel and Clawson 2014; Lott and Chung 2016; Powell and Craig 2015). Finally, the broad operationalization of flextime policies in the ATUS may mean that fathers may have access but may not feel they are able to use it (Williams et al. 2013), especially if the policy is an informal rather than a formal arrangement (Gerstel and Clawson 2014).

A puzzling finding related to flextime is that fathers who feel they "rarely" have access spend significantly less total time with their children and families compared to their peers with more frequent access and those without any flextime access. Spending less time together overall may be detrimental for family well-being (Musick, Meier, and Flood 2016; Snyder 2007); however, fathers may be preserving valuable time in childcare (e.g., Hsin and Felfe 2014). The reasons for this difference are unclear. Fathers may face stigma and a lack of support for using flexibility (Chung 2020b; Coltrane et al. 2013; Williams et al. 2013), or high work demands related to an ideal worker culture (Badawy and Schieman 2020; Schieman, Glavin, and Milkie 2009). Alternatively, these measures of access to flextime may capture perceptions of flexibility, which is higher when workers actually use informal or formal flexibility arrangements (Grzywacz, Carlson, and Shulkin 2008; Richman et al. 2008) and lower if fathers have heightened work and family demands (Grzywacz et al. 2008; Richman et al. 2008). Future research should attend to how father-child time is differently shaped by perceptions of, access to, and use of flexibility.

The novel finding that flextime and flexplace policies are associated with fathers' increased family time has critical, and potentially competing, implications for family well-being and gender inequality. Time together as a family may be especially valued or considered "quality" time, with benefits for lessening stress and improving a sense of family togetherness (Folbre et al. 2005; Roeters and Gracia 2016; Shaw and Dawson 2001; Snyder 2007). Further, 
the differences in family time are not only substantial - about an hour more daily for flexplaceusing fathers, for example - but also distributed across activities such as meals and leisure that are associated with higher subjective well-being (Musick et al. 2016). This family time may show that fathers are more embedded within the daily rhythms of their families and are able to be more present as parents.

Yet, how might "family" time matter for gender inequality in the division of care work particularly responsibility for children? Fathers stepping up to spend more family time with their children might not lead to mothers "stepping back." Notably, there are no associations between flexibility policies and fathers' time in solo parenting, which captures part of their responsibility for children (Craig 2006; Raley et al. 2012; Wray 2020). Fathers thus may not be substituting for mothers' time in care work, which means mothers are not free to pursue their own paid work or personal activities (Craig 2006; Raley et al. 2012). The dynamics of family time also matter for how responsibility is distributed. If mothers retain the role of primary parent in shared family time, this may preserve an unequal helper-manager dynamic. Conversely, family time may lead to parents sharing the responsibility for children and work of parenting, which may help to reduce stress and enhance family cohesion (Folbre et al. 2005; Shaw and Dawson 2001). Scholars should consider how fathers, mothers, and children interact in this "family time" to understand whether parents are actively co-parenting or whether fathers still take on a secondary role as parents. In addition, family time may lead to longer-term changes: by being exposed, even if temporarily, to the responsibilities and daily realities of caregiving, fathers may establish stronger orientations toward active fathering and may continue to prioritize time with children and families in the longer-term (Knoester et al. 2019; Rehel 2014; Wray 2020). Future research should elucidate how spending "family time" with children may affect fathering identities and the recognition of responsibility(s) for children. 
Although the ATUS Leave Module is a uniquely detailed data source, there are several limitations. First, the data are cross-sectional, providing only a snapshot of fathers' lives with their families, and limiting the consideration of selection effects. Fathers may select out of flexibility, given penalties due to flexibility stigma or demands from work (Chung 2020b; Coltrane et al. 2013; Williams et al. 2013); or they may select into flexibility, to mitigate workfamily conflict (Young and Schieman 2018) or because of a stronger orientation toward family. Second, as time diaries are only collected from one respondent per household, it is not possible to look at the dynamics of negotiations around caregiving within couples. Research on parental leave-taking suggests that gendered negotiation dynamics often reinforce mothers' identities as primary caregivers and fathers as breadwinners (Beglaubter 2017). This also limits an investigation of how the father's partner's workplace flexibility, which previous research shows may matter more than their own flexibility (Noonan et al. 2007). Third, this study examines a select sample of fathers - those who are employed and reside with their children. Future research should explore how class, race, the age and the number of children, and other factors likely intersect with this relationship (e.g., Gerstel and Clawson 2018).

In sum, this study provides new evidence on an increasingly popular institutional tool for work-family reconciliation in the liberal welfare state context of the United States. This evidence is particularly timely, given the ongoing reckoning with workplace flexibility taking place because of the COVID-19 pandemic (e.g., Chung et al. 2021). Flexibility policies are associated with father involvement, but this relationship is complex and is conditional on the frequency of access or use as well as how father-child time is conceptualized and measured. Flexibility policies, particularly flexplace, are associated with increased "family time" - where children and the mother are present. This family time may be uniquely beneficial for family well-being and togetherness, but may have more complex consequences for the unequal division of care work 
between mothers and fathers - especially responsibility for children. Ultimately, though, the evidence suggests that flexibility policies may be an important policy to mitigate time conflict between work and family roles and to expose, thus facilitating their desired involvement with their children.

\section{References}

Allen, Tammy D., Ryan C. Johnson, Kaitlin M. Kiburz, and Kristen M. Shockley. 2013. "WorkFamily Conflict and Flexible Work Arrangements: Deconstructing Flexibility." Personnel Psychology 66(2):345-76. doi: 10.1111/peps.12012.

Aumann, Kerstin, Ellen Galinsky, and Kenneth Matos. 2011. “The New Male Mystique.” Families and Work Institute.

Badawy, Philip J., and Scott Schieman. 2020. "Controlling or Channeling Demands? How Schedule Control Influences the Link between Job Pressure and the Work-Family Interface." Work and Occupations.

Baxter, Jennifer. 2011. "Flexible Work Hours and Other Job Factors in Parental Time with Children." Social Indicators Research 101(2):239-42. doi: 10.1007/s11205-010-9641-4.

Beglaubter, Judy. 2017. "Balancing the Scales: Negotiating Father's Parental Leave Use." Canadian Review of Sociology/Revue Canadienne de Sociologie 54(4):476-96. doi: 10.1111/cars.12173.

Bianchi, Suzanne M., John P. Robinson, and Melissa A. Milkie. 2006. The Changing Rhythms of American Family Life. Russell Sage Foundation.

Borgkvist, Ashlee, Jaklin Eliott, Shona Crabb, and Vivienne Moore. 2020. “'Unfortunately I'm a Massively Heavy Sleeper': An Analysis of Fathers' Constructions of Parenting." Men and Masculinities 23(3-4):680-701. doi: 10.1177/1097184X18809206.

Budig, Michelle J., and Nancy Folbre. 2004. “Activity, Proximity, or Responsibility? Measuring Parental Childcare Time." Pp. 51-68 in Family Time: The Social Organization of Care, edited by N. Folbre and M. Bittman. London: Routledge.

Carlson, Daniel L., Richard J. Petts, and Joanna R. Pepin. 2021. "Flexplace Work and Partnered Fathers' Time in Housework and Childcare." Men and Masculinities. doi: https://doi.org/10.1177\%2F1097184X211014929.

Christopher, Karen. 2012. "Extensive Mothering: Employed Mothers' Constructions of the Good Mother." Gender \& Society 26(1):73-96. doi: 10.1177/0891243211427700. 
Chung, Heejung. 2020a. "Company-Level Family Policies: Who Has Access to It and What Are Some of Its Outcomes?” Pp. 535-73 in The Palgrave Handbook of Family Policy, edited by R. Nieuwenhuis and W. Van Lancker. Cham: Springer International Publishing.

Chung, Heejung. 2020b. "Gender, Flexibility Stigma and the Perceived Negative Consequences of Flexible Working in the UK." Social Indicators Research 151(2):521-45. doi: 10.1007/s11205-018-2036-7.

Chung, Heejung, Holly Birkett, Sarah Forbes, and Hyojin Seo. 2021. "Covid-19, Flexible Working, and Implications for Gender Equality in the United Kingdom.” Gender \& Society 08912432211001304. doi: 10.1177/08912432211001304.

Coltrane, Scott. 2004. "Fathering: Paradoxes, Contradictions, and Dilemmas." in Handbook of Contemporary Families: Considering the Past, Contemplating the Future, edited by M. Coleman and L. Ganong. SAGE Publications, Inc.

Coltrane, Scott, Elizabeth C. Miller, Tracy DeHaan, and Lauren Stewart. 2013. "Fathers and the Flexibility Stigma.” Journal of Social Issues 69(2):279-302. doi: 10.1111/josi.12015.

Craig, Lyn. 2006. "Does Father Care Mean Fathers Share?: A Comparison of How Mothers and Fathers in Intact Families Spend Time with Children." Gender \& Society 20(2):259-81. doi: $10.1177 / 0891243205285212$.

Davis, Kelly D., Katie M. Lawson, David M. Almeida, Erin L. Kelly, Rosalind B. King, Leslie Hammer, Lynne M. Casper, Cassandra A. Okechukwu, Ginger Hanson, and Susan M. McHale. 2015. "Parents' Daily Time With Their Children: A Workplace Intervention." Pediatrics 135(5):875-82. doi: 10.1542/peds.2014-2057.

Dean, Annie, and Anna Auerbach. 2018. "96\% of U.S. Professionals Say They Need Flexibility, but Only 47\% Have It.” Harvard Business Review, June 5.

Doucet, Andrea. 2015. "Parental Responsibilities: Dilemmas of Measurement and Gender Equality." Journal of Marriage and Family 77(1):224-42. doi: 10.1111/jomf.12148.

Dunatchik, Allison, and Svetlana Speight. 2020. "Re-Examining How Partner Co-Presence and Multitasking Affect Parents' Enjoyment of Childcare and Housework." Sociological Science 7:268-90. doi: 10.15195/v7.a11.

Folbre, Nancy, Jayoung Yoon, Kade Finnoff, and Allison Sidle Fuligni. 2005. "By What Measure? Family Time Devoted to Children in the United States." Demography 42(2):373-90. doi: 10.1353/dem.2005.0013.

Genadek, Katie R., and Rachelle Hill. 2017. "Parents' Work Schedules and Time Spent with Children." Community, Work \& Family 20(5):523-42. doi: 10.1080/13668803.2017.1371672.

Gerstel, Naomi, and Dan Clawson. 2014. "Class Advantage and the Gender Divide: Flexibility on the Job and at Home." American Journal of Sociology 120(2):395-431. doi: $10.1086 / 678270$. 
Gerstel, Naomi, and Dan Clawson. 2018. "Control over Time: Employers, Workers, and Families Shaping Work Schedules." Annual Review of Sociology 44(1):77-97. doi: 10.1146/annurev-soc-073117-041400.

Gornick, Janet C., and Marcia K. Meyers. 2003. Families That Work: Policies for Reconciling Parenthood and Employment. Russell Sage Foundation.

Greenhaus, Jeffrey H., and Nicholas J. Beutell. 1985. "Sources of Conflict between Work and Family Roles.” The Academy of Management Review 10(1):76-88. doi: 10.2307/258214.

Grzywacz, Joseph G., Dawn S. Carlson, and Sandee Shulkin. 2008. "Schedule Flexibility and Stress: Linking Formal Flexible Arrangements and Perceived Flexibility to Employee Health." Community, Work \& Family 11(2):199-214. doi: 10.1080/13668800802024652.

Hays, Sharon. 1996. The Cultural Contradictions of Motherhood. New Haven, CT: Yale University Press.

Hill, Jeffrey E., Joseph G. Grzywacz, Sarah Allen, Victoria L. Blanchard, Christina Matz-Costa, Sandee Shulkin, and Marcie Pitt-Catsouphes. 2008. "Defining and Conceptualizing Workplace Flexibility." Community, Work \& Family 11(2):149-63. doi: 10.1080/13668800802024678.

Hill, Rachelle, Eric Tranby, Erin Kelly, and Phyllis Moen. 2013. "Relieving the Time Squeeze? Effects of a White-Collar Workplace Change on Parents." Journal of Marriage and Family 75(4):1014-29. doi: https://doi.org/10.1111/jomf.12047.

Hofferth, Sandra L., Sarah M. Flood, Matthew Sobek, and Daniel Backman. 2020. American Time Use Survey Data Extract Builder: Version 2.8 [Dataset]. Minneapolis, MN: IPUMS.

Hsin, Amy, and Christina Felfe. 2014. "When Does Time Matter? Maternal Employment, Children's Time with Parents, and Child Development." Demography 51(5):1867-94. doi: 10.1007/s13524-014-0334-5.

Jacobs, Jerry A., and Kathleen Gerson. 2004. The Time Divide: Work, Family, and Gender Inequality. Cambridge, MA: Harvard University Press.

Kim, Jaeseung. 2020. "Workplace Flexibility and Parent-Child Interactions Among Working Parents in the U.S." Social Indicators Research 151(2):427-69. doi: 10.1007/s11205018-2032-y.

Knoester, Chris, Richard J. Petts, and Brianne Pragg. 2019. "Paternity Leave-Taking and Father Involvement among Socioeconomically Disadvantaged U.S. Fathers.” Sex Roles 88(56):257-61. doi: 10.1007/s11199-018-0994-5.

Kroska, Amy, and Cheryl Elman. 2009. "Change in Attitudes about Employed Mothers: Exposure, Interests, and Gender Ideology Discrepancies." Social Science Research 38(2):366-82. doi: 10.1016/j.ssresearch.2008.12.004. 
Lamb, Michael E. 2000. "The History of Research on Father Involvement: An Overview." Marriage and Family Review 29(2):23-42.

Lott, Yvonne, and Heejung Chung. 2016. "Gender Discrepancies in the Outcomes of Schedule Control on Overtime Hours and Income in Germany." European Sociological Review 32(6):752-65. doi: 10.1093/esr/jcw032.

Lyttelton, Thomas, Emma Zang, and Kelly Musick. 2020. "Gender Differences in Telecommuting and Implications for Inequality at Home and Work." doi: https://dx.doi.org/10.2139/ssrn.3645561.

Milkie, Melissa A., Marybeth J. Mattingly, Kei M. Nomaguchi, Suzanne M. Bianchi, and John P. Robinson. 2004. "The Time Squeeze: Parental Statuses and Feelings About Time With Children." Journal of Marriage and Family 66(3):739-61. doi: 10.1111/j.00222445.2004.00050.x.

Milkie, Melissa A., Kei Nomaguchi, and Scott Schieman. 2019. "Time Deficits with Children: The Link to Parents' Mental and Physical Health." Society and Mental Health 9(3):27795. doi: $10.1177 / 2156869318767488$.

Mullan, Killian, and Lyn Craig. 2009. "Harmonising Extended Measures of Parental Childcare in the Time-Diary Surveys of Four Countries - Proximity Versus Responsibility." Electronic International Journal of Time Use Research 6(1):48-72. doi: 10.13085/eIJTUR.6.1.48-72.

Munsch, Christin L. 2016. "Flexible Work, Flexible Penalties: The Effect of Gender, Childcare, and Type of Request on the Flexibility Bias." Social Forces 94(4):1567-91. doi: $10.1093 / \mathrm{s} / \mathrm{sov} 122$.

Musick, Kelly, Ann Meier, and Sarah Flood. 2016. "How Parents Fare: Mothers' and Fathers' Subjective Well-Being in Time with Children." American Sociological Review 81(5):1069-95. doi: 10.1177/0003122416663917.

Nomaguchi, Kei M., Melissa A. Milkie, and Suzanne M. Bianchi. 2005. "Time Strains and Psychological Well-Being: Do Dual-Earner Mothers and Fathers Differ?" Journal of Family Issues 26(6):756-92. doi: 10.1177/0192513X05277524.

Noonan, Mary C., Sarah Beth Estes, and Jennifer L. Glass. 2007. "Do Workplace Flexibility Policies Influence Time Spent in Domestic Labor?” Journal of Family Issues 28(2):26388. doi: 10.1177/0192513X06292703.

Pabilonia, Sabrina Wulff, and Victoria Vernon. 2020. "Telework and Time Use in the United States."

Powell, Abigail, and Lyn Craig. 2015. "Gender Differences in Working at Home and Time Use Patterns: Evidence from Australia." Work, Employment and Society 29(4):571-89. doi: $10.1177 / 0950017014568140$. 
Raley, Sara, Suzanne M. Bianchi, and Wendy Wang. 2012. "When Do Fathers Care? Mothers' Economic Contribution and Fathers' Involvement in Child Care." American Journal of Sociology 117(5):1422-59. doi: 10.1086/663354.

Rapoport, Benoît, and Céline Le Bourdais. 2008. "Parental Time and Working Schedules." Journal of Population Economics 21(4):903-32. doi: 10.1007/s00148-007-0147-6.

Rehel, Erin M. 2014. "When Dad Stays Home Too: Paternity Leave, Gender, and Parenting." Gender \& Society 28(1):110-32. doi: 10.1177/0891243213503900.

Richman, Amy L., Janet T. Civian, Laurie L. Shannon, E. Jeffrey Hill, and Robert T. Brennan. 2008. "The Relationship of Perceived Flexibility, Supportive Work-Life Policies, and Use of Formal Flexible Arrangements and Occasional Flexibility to Employee Engagement and Expected Retention." Community, Work \& Family 11(2):183-97. doi: $10.1080 / 13668800802050350$.

Risman, Barbara J. 1998. Gender Vertigo: American Families in Transition. Yale University Press.

Roeters, Anne, and Pablo Gracia. 2016. "Child Care Time, Parents' Well-Being, and Gender: Evidence from the American Time Use Survey." Journal of Child and Family Studies 25(8):2469-79. doi: 10.1007/s10826-016-0416-7.

Rudman, Laurie A., and Kris Mescher. 2013. "Penalizing Men Who Request a Family Leave: Is Flexibility Stigma a Femininity Stigma?” Journal of Social Issues 69(2):322-40. doi: 10.1111/josi.12017.

Schieman, Scott, Paul Glavin, and Melissa A. Milkie. 2009. "When Work Interferes with Life: Work-Nonwork Interference and the Influence of Work-Related Demands and Resources." American Sociological Review 74:966-88.

Shaw, Susan M. 2008. "Family Leisure and Changing Ideologies of Parenthood." Sociology Compass 2(2):688-703. doi: https://doi.org/10.1111/j.1751-9020.2007.00076.x.

Shaw, Susan M., and Don Dawson. 2001. "Purposive Leisure: Examining Parental Discourses on Family Activities.” Leisure Sciences 23(4):217-31. doi: 10.1080/01490400152809098.

Snyder, Karrie Ann. 2007. "A Vocabulary of Motives: Understanding How Parents Define Quality Time.” Journal of Marriage and Family 69(2):320-40. doi: 10.1111/j.17413737.2007.00368.x.

Townsend, Nicholas. 2002. The Package Deal: Marriage, Work, and Fatherhood in Men's Lives. Philadelphia: Temple University Press.

U.S. Bureau of Labor Statistics. 2019. Job Flexibilities and Work Schedules Summary.

Wall, Glenda, and Stephanie Arnold. 2007. "How Involved Is Involved Fathering?: An Exploration of the Contemporary Culture of Fatherhood." Gender \& Society 21(4):50827. doi: $10.1177 / 0891243207304973$. 
Wight, Vanessa R., and Sara B. Raley. 2008. "When Home Becomes Work: Work and Family Time among Workers at Home.” Social Indicators Research 93(1):197. doi: 10.1007/s11205-008-9377-6.

Williams, Joan C., Mary Blair-Loy, and Jennifer L. Berdahl. 2013. "Cultural Schemas, Social Class, and the Flexibility Stigma: Cultural Schemas and Social Class." Journal of Social Issues 69(2):209-34. doi: 10.1111/josi.12012.

Wilson, Katherine R., and Margot R. Prior. 2010. "Father Involvement: The Importance of Paternal Solo Care.” Early Child Development and Care 180(10):1391-1405. doi: 10.1080/03004430903172335.

Wray, Dana. 2020. "Paternity Leave and Fathers' Responsibility: Evidence From a Natural Experiment in Canada." Journal of Marriage and Family 82(2):534-49. doi: 10.1111/jomf.12661.

Wray, Dana, Julia Ingenfeld, Melissa A. Milkie, and Irene Boeckmann. 2021. "Parent-Child Time Beyond Childcare: Contact and Childcare Time in Canada over Three Decades." Canadian Review of Sociology 58(3):327-51. doi: https://doi.org/10.1111/cars.12356.

Young, Marisa, and Scott Schieman. 2018. "Scaling Back and Finding Flexibility: Gender Differences in Parents' Strategies to Manage Work-Family Conflict.” Journal of Marriage and Family 80(1):99-118. doi: 10.1111/jomf.12435. 


\section{Appendix}

Table A.1: OLS regression estimates for flextime access and fathers' time with children

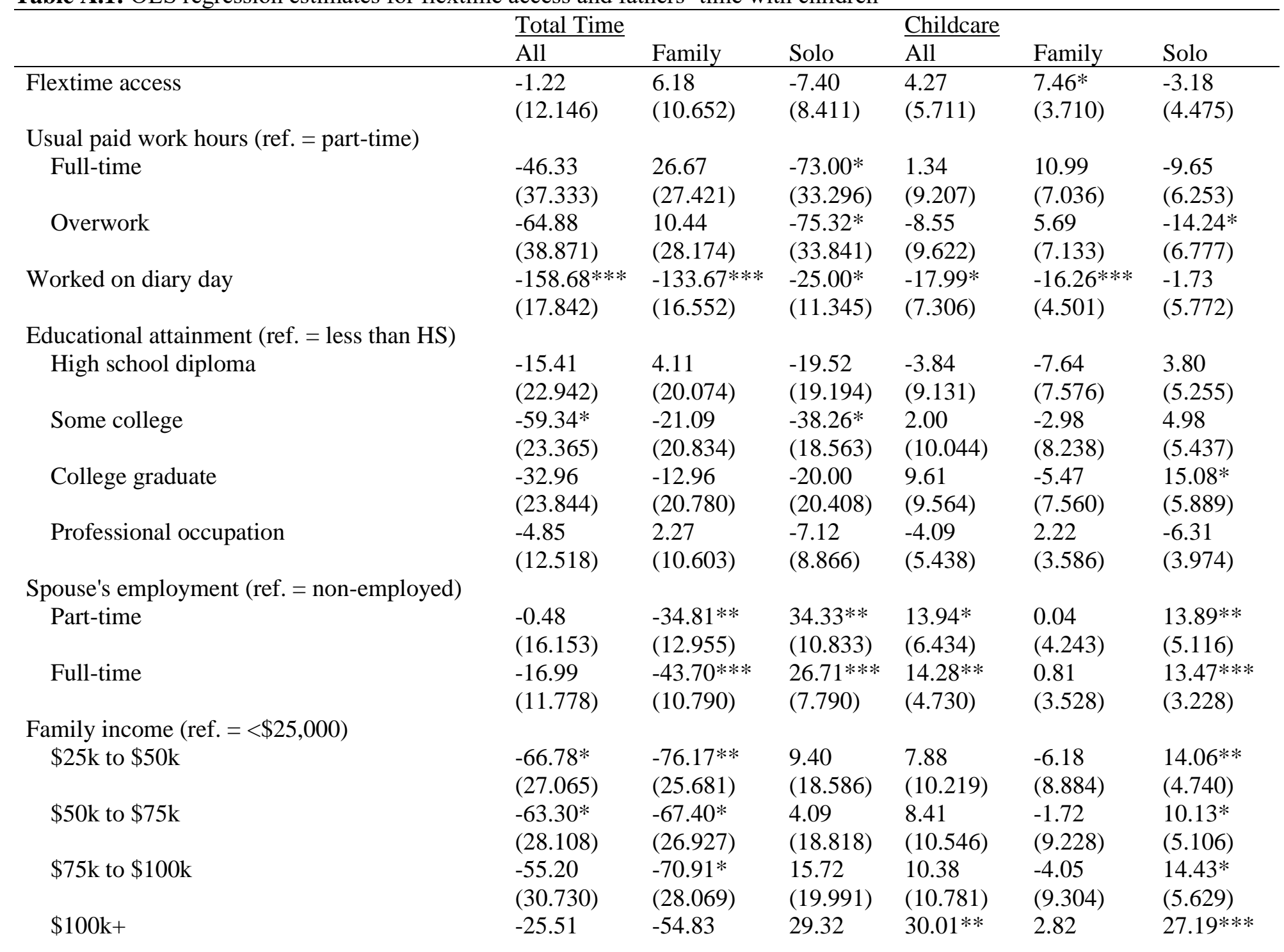




\begin{tabular}{|c|c|c|c|c|c|c|}
\hline & \multicolumn{3}{|l|}{ Total Time } & \multicolumn{3}{|l|}{ Childcare } \\
\hline & $\overline{\text { All }}$ & Family & Solo & $\overline{\text { All }}$ & Family & Solo \\
\hline & $(29.195)$ & $(28.193)$ & $(19.284)$ & $(11.530)$ & $(9.597)$ & $(6.870)$ \\
\hline \multicolumn{7}{|l|}{ Race (ref. = white) } \\
\hline \multirow[t]{2}{*}{ Black } & -24.47 & -16.41 & -8.06 & -8.22 & $-10.42 * *$ & 2.20 \\
\hline & (19.946) & (18.387) & $(13.370)$ & $(7.080)$ & $(3.743)$ & (6.219) \\
\hline \multirow[t]{2}{*}{ Latinx } & -5.22 & 6.93 & -12.16 & -8.11 & -1.24 & -6.87 \\
\hline & $(18.502)$ & $(14.637)$ & $(12.702)$ & $(7.730)$ & $(5.691)$ & $(5.024)$ \\
\hline \multirow[t]{2}{*}{ Other } & 20.15 & $37.91 *$ & -17.77 & -4.04 & 2.81 & -6.85 \\
\hline & $(15.285)$ & $(14.880)$ & $(9.883)$ & $(5.943)$ & $(4.298)$ & $(4.541)$ \\
\hline \multirow[t]{2}{*}{ Age } & -0.23 & -0.91 & 0.68 & $-0.87 * *$ & $-0.76 * * *$ & -0.11 \\
\hline & $(0.763)$ & $(0.675)$ & $(0.459)$ & $(0.266)$ & $(0.190)$ & $(0.198)$ \\
\hline \multirow[t]{2}{*}{ Cohabiting } & $-48.03 *$ & -38.69 & -9.34 & $-20.38 *$ & -11.29 & -9.09 \\
\hline & $(20.694)$ & (19.842) & $(13.696)$ & $(7.971)$ & $(6.459)$ & $(6.163)$ \\
\hline \multicolumn{7}{|c|}{ Age of youngest child (ref. $=0-5$ years old) } \\
\hline \multirow[t]{2}{*}{ 6-12 years old } & $-29.51 *$ & $-27.90 *$ & -1.62 & $-38.05 * * *$ & $-18.51 * * *$ & $-19.54 * * *$ \\
\hline & $(12.753)$ & $(11.307)$ & $(8.472)$ & $(5.486)$ & $(3.848)$ & $(4.001)$ \\
\hline \multirow[t]{2}{*}{$13-17$ years old } & $-129.83 * * *$ & $-95.98 * * *$ & $-33.84 * *$ & $-59.08 * * *$ & $-29.17 * * *$ & $-29.91 * * *$ \\
\hline & $(17.557)$ & $(15.452)$ & $(10.567)$ & $(6.713)$ & $(3.933)$ & $(5.409)$ \\
\hline \multirow[t]{2}{*}{ Number of own $\mathrm{HH}$ kids under 18} & $14.84 *$ & -3.16 & $18.00 * * *$ & 0.07 & -1.98 & 2.05 \\
\hline & $(6.126)$ & $(5.034)$ & $(4.262)$ & $(2.631)$ & $(1.547)$ & $(2.087)$ \\
\hline \multirow[t]{2}{*}{ Weekend diary } & $147.76 * * *$ & $113.09 * * *$ & $34.67 * * *$ & 8.98 & 1.95 & 7.04 \\
\hline & $(16.388)$ & $(15.023)$ & $(10.356)$ & $(6.738)$ & $(3.702)$ & $(5.718)$ \\
\hline \multirow[t]{2}{*}{ Holiday diary } & $133.26 * * *$ & $114.21 *$ & 19.05 & -23.91 & -8.32 & -15.59 \\
\hline & $(37.811)$ & (52.199) & $(35.984)$ & $(22.992)$ & $(22.228)$ & $(9.731)$ \\
\hline \multirow[t]{2}{*}{ Summer diary } & 1.43 & -1.13 & 2.56 & -5.19 & -6.50 & 1.31 \\
\hline & $(13.335)$ & (12.107) & $(8.659)$ & $(5.378)$ & $(3.440)$ & $(4.509)$ \\
\hline \multirow[t]{2}{*}{ Flextime is formal policy } & 7.97 & -9.82 & 17.79 & 5.40 & 0.60 & 4.80 \\
\hline & $(14.412)$ & $(12.214)$ & $(10.130)$ & $(6.659)$ & $(4.704)$ & $(4.780)$ \\
\hline \multirow[t]{2}{*}{ Schedule input but no flextime } & 33.64 & 40.35 & -6.71 & -0.45 & 7.31 & -7.76 \\
\hline & $(21.740)$ & $(22.149)$ & $(13.972)$ & $(7.111)$ & $(5.625)$ & $(5.088)$ \\
\hline \multirow[t]{2}{*}{ Constant } & $485.20 * * *$ & $383.44 * * *$ & 101.76 & $100.46 * * *$ & $77.68 * * *$ & 22.78 \\
\hline & $(60.153)$ & $(50.891)$ & $(54.357)$ & $(20.104)$ & $(15.860)$ & (11.675) \\
\hline
\end{tabular}

Note: ATUS 2017-2018 Leave Module. Total N=1,882. Analyses are weighted with Leave Module population and replicate weights. 
Table A.2: OLS regression estimates for frequency of flextime access and fathers' time with children

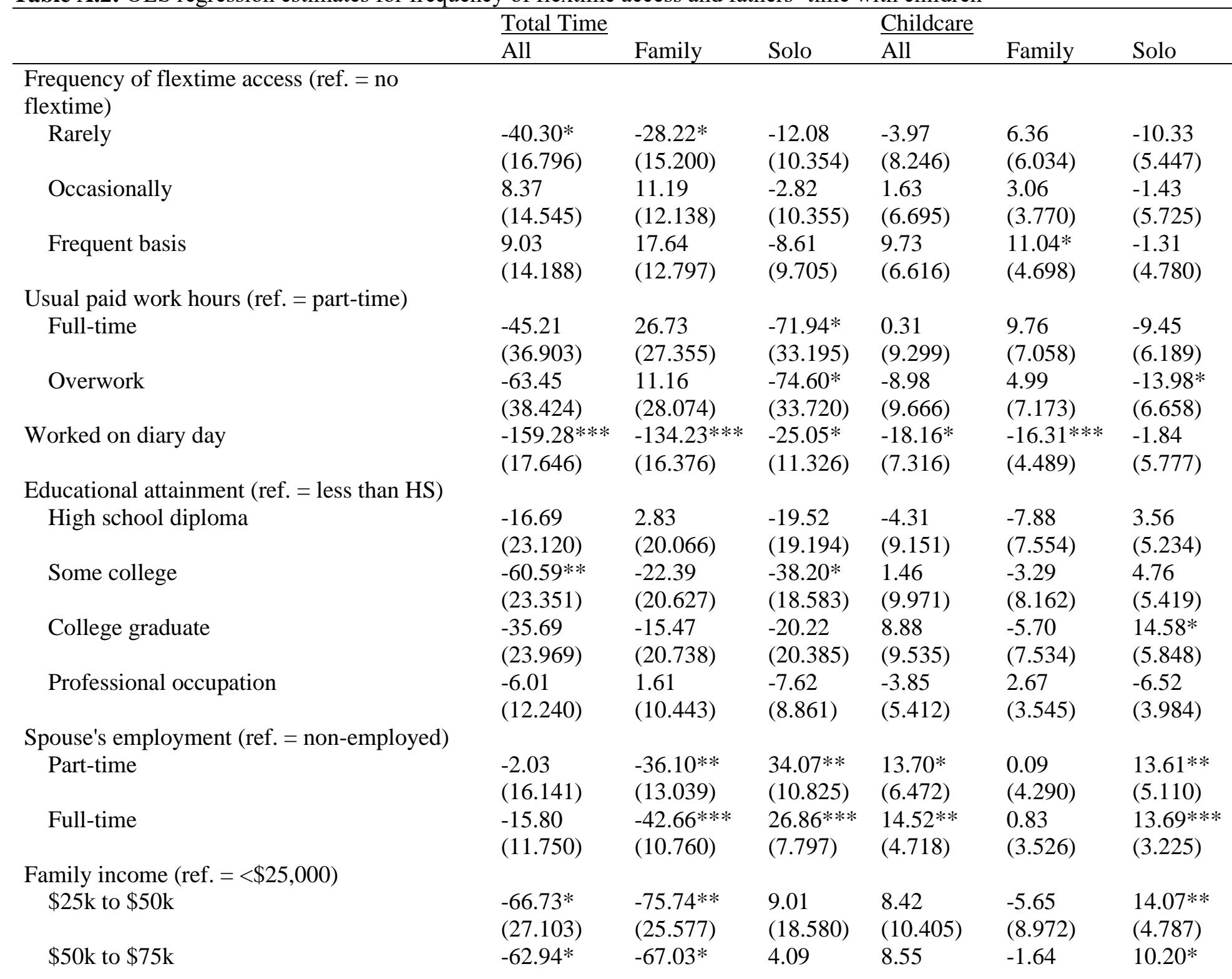




\begin{tabular}{|c|c|c|c|c|c|c|}
\hline \multicolumn{7}{|c|}{$\underline{\text { Total Time }}$} \\
\hline & $\overline{\text { All }}$ & Family & Solo & $\overline{\text { All }}$ & Family & Solo \\
\hline \multirow{3}{*}{$\$ 75 \mathrm{k}$ to $\$ 100 \mathrm{k}$} & $(28.100)$ & $(26.777)$ & $(18.866)$ & $(10.703)$ & $(9.302)$ & $(5.090)$ \\
\hline & -54.97 & $-70.47 *$ & 15.50 & 10.76 & -3.71 & $14.47 *$ \\
\hline & $(30.716)$ & $(27.961)$ & $(20.005)$ & $(10.948)$ & $(9.395)$ & $(5.619)$ \\
\hline \multirow[t]{2}{*}{$\$ 100 \mathrm{k}+$} & -25.30 & -54.21 & 28.90 & $30.65 * *$ & 3.43 & $27.22 * * *$ \\
\hline & $(29.091)$ & $(28.014)$ & (19.321) & (11.694) & $(9.732)$ & $(6.851)$ \\
\hline \multicolumn{7}{|l|}{ Race (ref. = white) } \\
\hline \multirow[t]{2}{*}{ Black } & -25.22 & -17.13 & -8.09 & -8.46 & $-10.52 * *$ & 2.06 \\
\hline & $(20.101)$ & (18.599) & $(13.368)$ & $(6.963)$ & $(3.746)$ & $(6.163)$ \\
\hline \multirow[t]{2}{*}{ Latinx } & -2.08 & 9.47 & -11.55 & -7.76 & -1.46 & -6.30 \\
\hline & $(18.314)$ & $(14.437)$ & $(12.739)$ & (7.699) & $(5.624)$ & $(5.040)$ \\
\hline \multirow[t]{2}{*}{ Other } & 24.49 & $41.56^{* *}$ & -17.07 & -3.36 & 2.69 & -6.05 \\
\hline & $(15.520)$ & $(15.085)$ & $(10.003)$ & $(5.966)$ & $(4.275)$ & $(4.582)$ \\
\hline \multirow[t]{2}{*}{ Age } & -0.42 & -1.07 & 0.65 & $-0.90 * * *$ & $-0.76 * * *$ & -0.14 \\
\hline & $(0.755)$ & $(0.664)$ & $(0.462)$ & $(0.262)$ & $(0.190)$ & $(0.199)$ \\
\hline \multirow[t]{2}{*}{ Cohabiting } & $-45.62 *$ & -36.39 & -9.23 & $-19.62 *$ & -10.97 & -8.65 \\
\hline & $(20.930)$ & (19.812) & $(13.727)$ & $(7.933)$ & $(6.513)$ & $(6.206)$ \\
\hline \multicolumn{7}{|c|}{ Age of youngest child (ref. $=0-5$ years old) } \\
\hline \multirow[t]{2}{*}{ 6-12 years old } & $-26.52 *$ & $-25.49 *$ & -1.03 & $-37.72 * * *$ & $-18.73 * * *$ & $-19.00 * * *$ \\
\hline & $(12.805)$ & $(11.294)$ & $(8.518)$ & $(5.433)$ & $(3.827)$ & $(3.960)$ \\
\hline \multirow[t]{2}{*}{ 13-17 years old } & $-126.06 * * *$ & $-92.90 * * *$ & $-33.16 * *$ & $-58.60 * * *$ & $-29.38 * * *$ & $-29.22 * * *$ \\
\hline & $(17.374)$ & $(15.247)$ & $(10.670)$ & $(6.673)$ & $(3.982)$ & $(5.352)$ \\
\hline \multirow[t]{2}{*}{ Number of own HH kids under 18} & $14.95 *$ & -2.94 & $17.89 * * *$ & 0.27 & -1.80 & 2.07 \\
\hline & $(6.153)$ & $(5.013)$ & $(4.287)$ & $(2.645)$ & $(1.585)$ & $(2.070)$ \\
\hline \multirow[t]{2}{*}{ Weekend diary } & $147.84 * * *$ & $113.09 * * *$ & $34.75 * * *$ & 8.90 & 1.85 & 7.05 \\
\hline & $(16.206)$ & $(14.853)$ & $(10.333)$ & $(6.744)$ & $(3.689)$ & $(5.715)$ \\
\hline \multirow[t]{2}{*}{ Holiday diary } & $127.25 * * *$ & $108.70 *$ & 18.55 & -25.48 & -8.80 & -16.68 \\
\hline & $(37.898)$ & $(52.211)$ & $(36.071)$ & $(22.583)$ & $(22.014)$ & (9.709) \\
\hline \multirow[t]{2}{*}{ Summer diary } & 2.04 & -0.92 & 2.96 & -5.50 & $-6.92 *$ & 1.42 \\
\hline & (13.242) & (12.017) & $(8.686)$ & $(5.394)$ & $(3.463)$ & $(4.509)$ \\
\hline \multirow[t]{2}{*}{ Flextime is formal policy } & 11.14 & -6.73 & 17.87 & 6.48 & 1.10 & 5.38 \\
\hline & $(14.492)$ & $(12.344)$ & (10.083) & $(6.630)$ & $(4.736)$ & $(4.868)$ \\
\hline \multirow[t]{2}{*}{ Schedule input but no flextime } & 34.75 & 41.23 & -6.48 & -0.35 & 7.21 & -7.56 \\
\hline & $(21.753)$ & $(22.157)$ & (13.977) & $(7.106)$ & $(5.605)$ & $(5.098)$ \\
\hline Constant & $490.02 * * *$ & $388.08 * * *$ & 101.94 & $102.02 * * *$ & $78.35 * * *$ & $23.67 *$ \\
\hline
\end{tabular}




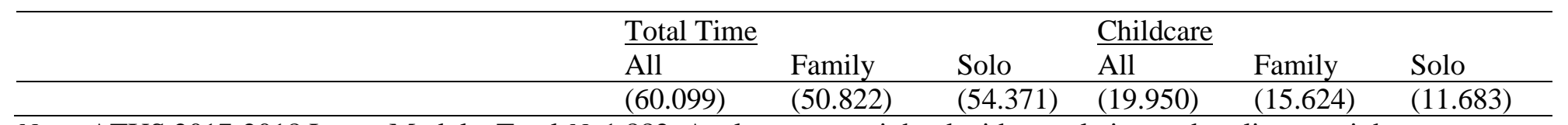

Note: ATUS 2017-2018 Leave Module. Total $N=1,882$. Analyses are weighted with population and replicate weights. 
Table A.3: OLS regression estimates for flexplace use and fathers' time with children

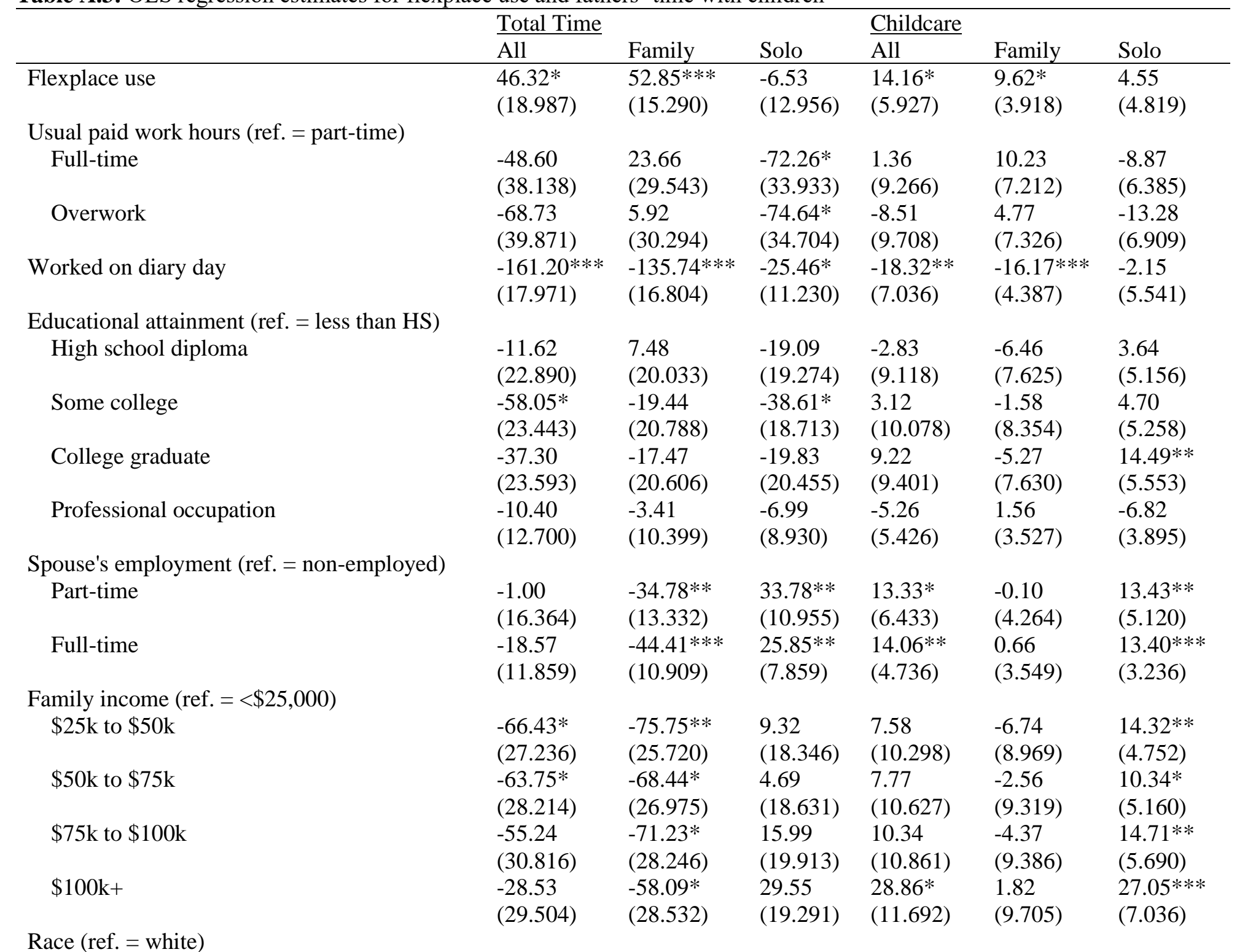

Race (ref. $=$ white $)$ 


\begin{tabular}{|c|c|c|c|c|c|c|}
\hline & \multicolumn{3}{|l|}{ Total Time } & \multicolumn{3}{|l|}{ Childcare } \\
\hline & All & Family & Solo & All & Family & Solo \\
\hline Black & $\begin{array}{l}-23.53 \\
(20.397)\end{array}$ & $\begin{array}{l}-17.23 \\
(19.063)\end{array}$ & $\begin{array}{l}-6.30 \\
(13.563)\end{array}$ & $\begin{array}{l}-7.65 \\
(7.016)\end{array}$ & $\begin{array}{l}-10.40 * * \\
(3.545)\end{array}$ & $\begin{array}{l}2.74 \\
(6.257)\end{array}$ \\
\hline Latinx & $\begin{array}{l}-3.80 \\
(18.523)\end{array}$ & $\begin{array}{l}7.40 \\
(14.622)\end{array}$ & $\begin{array}{l}-11.20 \\
(12.746)\end{array}$ & $\begin{array}{l}-7.07 \\
(7.680)\end{array}$ & $\begin{array}{l}-1.01 \\
(5.682)\end{array}$ & $\begin{array}{l}-6.06 \\
(5.058)\end{array}$ \\
\hline Other & $\begin{array}{l}18.38 \\
(15.280)\end{array}$ & $\begin{array}{l}36.19 * \\
(14.734)\end{array}$ & $\begin{array}{l}-17.81 \\
(9.885)\end{array}$ & $\begin{array}{l}-3.74 \\
(5.960)\end{array}$ & $\begin{array}{l}2.85 \\
(4.294)\end{array}$ & $\begin{array}{l}-6.60 \\
(4.571)\end{array}$ \\
\hline Age & $\begin{array}{l}-0.23 \\
(0.765)\end{array}$ & $\begin{array}{l}-0.94 \\
(0.679)\end{array}$ & $\begin{array}{l}0.70 \\
(0.457)\end{array}$ & $\begin{array}{l}-0.86 * * \\
(0.262)\end{array}$ & $\begin{array}{l}-0.76 * * * \\
(0.187)\end{array}$ & $\begin{array}{l}-0.10 \\
(0.195)\end{array}$ \\
\hline Cohabiting & $\begin{array}{l}-47.18 * \\
(20.609)\end{array}$ & $\begin{array}{l}-39.08 * \\
(19.874)\end{array}$ & $\begin{array}{l}-8.10 \\
(14.008)\end{array}$ & $\begin{array}{l}-19.38 * \\
(7.955)\end{array}$ & $\begin{array}{l}-10.36 \\
(6.288)\end{array}$ & $\begin{array}{l}-9.02 \\
(6.348)\end{array}$ \\
\hline Age of youngest child (ref. $=0-5$ ye & & & & & & \\
\hline 6-12 years old & $\begin{array}{l}-29.04 * \\
(12.564)\end{array}$ & $\begin{array}{l}-26.56^{*} \\
(11.158)\end{array}$ & $\begin{array}{l}-2.48 \\
(8.447)\end{array}$ & $\begin{array}{l}-38.09 * * * \\
(5.385)\end{array}$ & $\begin{array}{l}-18.23 * * * \\
(3.776)\end{array}$ & $\begin{array}{l}-19.87 * * * \\
(3.950)\end{array}$ \\
\hline 13-17 years old & $\begin{array}{l}-129.96 * * * \\
(17.573)\end{array}$ & $\begin{array}{l}-95.22 * * * \\
(15.459)\end{array}$ & $\begin{array}{l}-34.74 * * \\
(10.648)\end{array}$ & $\begin{array}{l}-59.68 * * * \\
(6.648)\end{array}$ & $\begin{array}{l}-29.31 * * * \\
(3.859)\end{array}$ & $\begin{array}{l}-30.37 * * * \\
(5.410)\end{array}$ \\
\hline Number of own HH kids under 18 & $\begin{array}{l}14.38 * \\
(6.126)\end{array}$ & $\begin{array}{l}-3.41 \\
(5.011)\end{array}$ & $\begin{array}{l}17.79 * * * \\
(4.298)\end{array}$ & $\begin{array}{l}-0.08 \\
(2.647)\end{array}$ & $\begin{array}{l}-2.10 \\
(1.542)\end{array}$ & $\begin{array}{l}2.03 \\
(2.110)\end{array}$ \\
\hline Weekend diary & $\begin{array}{l}146.35 * * * \\
(16.343)\end{array}$ & $\begin{array}{l}112.20 * * * \\
(15.102)\end{array}$ & $\begin{array}{l}34.15 * * * \\
(10.231)\end{array}$ & $\begin{array}{l}9.00 \\
(6.546)\end{array}$ & $\begin{array}{l}2.28 \\
(3.733)\end{array}$ & $\begin{array}{l}6.71 \\
(5.497)\end{array}$ \\
\hline Holiday diary & $\begin{array}{l}128.32 * * * \\
(38.160)\end{array}$ & $\begin{array}{l}111.12 * \\
(53.109)\end{array}$ & $\begin{array}{l}17.20 \\
(36.110)\end{array}$ & $\begin{array}{l}-24.53 \\
(23.213)\end{array}$ & $\begin{array}{l}-8.35 \\
(22.635)\end{array}$ & $\begin{array}{l}-16.18 \\
(9.190)\end{array}$ \\
\hline Summer diary & $\begin{array}{l}2.56 \\
(13.444)\end{array}$ & $\begin{array}{l}0.09 \\
(12.147)\end{array}$ & $\begin{array}{l}2.47 \\
(8.714)\end{array}$ & $\begin{array}{l}-4.68 \\
(5.305)\end{array}$ & $\begin{array}{l}-5.96 \\
(3.406)\end{array}$ & $\begin{array}{l}1.28 \\
(4.466)\end{array}$ \\
\hline Access to flexplace & $\begin{array}{l}23.04 \\
(17.517)\end{array}$ & $\begin{array}{l}32.49 * \\
(14.323)\end{array}$ & $\begin{array}{l}-9.44 \\
(11.401)\end{array}$ & $\begin{array}{l}0.34 \\
(5.146)\end{array}$ & $\begin{array}{l}4.38 \\
(3.767)\end{array}$ & $\begin{array}{l}-4.04 \\
(3.842)\end{array}$ \\
\hline Constant & $\begin{array}{l}489.98 * * * \\
(60.999)\end{array}$ & $\begin{array}{l}390.62 * * * \\
(52.898)\end{array}$ & $\begin{array}{l}99.35 \\
(54.335)\end{array}$ & $\begin{array}{l}101.68 * * * \\
(20.263)\end{array}$ & $\begin{array}{l}80.94 * * * \\
(16.099)\end{array}$ & $\begin{array}{l}20.74 \\
(11.942)\end{array}$ \\
\hline
\end{tabular}

Note: ATUS 2017-2018 Leave Module. Total $N=1,882$. Analyses are weighted with population and replicate weights. 
Table A.4: OLS regression estimates for reasons for flexplace use and fathers' time with children

\begin{tabular}{|c|c|c|c|c|c|c|}
\hline & \multicolumn{3}{|l|}{$\underline{\text { Total Time }}$} & \multicolumn{3}{|l|}{ Childcare } \\
\hline & $\overline{\text { All }}$ & Family & Solo & $\overline{\text { All }}$ & Family & Solo \\
\hline \multicolumn{7}{|c|}{$\begin{array}{l}\text { Reasons for flexplace use (ref. }=\text { no flexplace } \\
\text { use) }\end{array}$} \\
\hline Family reasons & $\begin{array}{l}48.11 \\
(25.954)\end{array}$ & $\begin{array}{l}47.36^{*} \\
(20.895)\end{array}$ & $\begin{array}{l}0.74 \\
(20.056)\end{array}$ & $\begin{array}{l}20.42 \\
(10.802)\end{array}$ & $\begin{array}{l}11.64 * \\
(5.792)\end{array}$ & $\begin{array}{l}8.78 \\
(9.383)\end{array}$ \\
\hline Work reasons & $\begin{array}{l}54.23 * \\
(21.428)\end{array}$ & $\begin{array}{l}56.16 * * \\
(17.396)\end{array}$ & $\begin{array}{l}-1.93 \\
(15.008)\end{array}$ & $\begin{array}{l}11.24 \\
(8.350)\end{array}$ & $\begin{array}{l}5.77 \\
(5.152)\end{array}$ & $\begin{array}{l}5.47 \\
(7.212)\end{array}$ \\
\hline Other reasons & $\begin{array}{l}26.81 \\
(25.443)\end{array}$ & $\begin{array}{l}49.53^{*} \\
(22.150)\end{array}$ & $\begin{array}{l}-22.71 \\
(14.266)\end{array}$ & $\begin{array}{l}12.75 \\
(7.955)\end{array}$ & $\begin{array}{l}14.34 * \\
(6.441)\end{array}$ & $\begin{array}{l}-1.59 \\
(5.370)\end{array}$ \\
\hline \multicolumn{7}{|c|}{ Usual paid work hours (ref. $=$ part-time) } \\
\hline Full-time & $\begin{array}{l}-48.67 \\
(38.038)\end{array}$ & $\begin{array}{l}23.71 \\
(29.520)\end{array}$ & $\begin{array}{l}-72.38 * \\
(33.926)\end{array}$ & $\begin{array}{l}1.28 \\
(9.256)\end{array}$ & $\begin{array}{l}10.22 \\
(7.211)\end{array}$ & $\begin{array}{l}-8.94 \\
(6.385)\end{array}$ \\
\hline Overwork & $\begin{array}{l}-68.99 \\
(39.782)\end{array}$ & $\begin{array}{l}5.74 \\
(30.284)\end{array}$ & $\begin{array}{l}-74.73 * \\
(34.690)\end{array}$ & $\begin{array}{l}-8.34 \\
(9.690)\end{array}$ & $\begin{array}{l}4.93 \\
(7.325)\end{array}$ & $\begin{array}{l}-13.27 \\
(6.892)\end{array}$ \\
\hline \multicolumn{7}{|c|}{ Educational attainment (ref. = less than HS) } \\
\hline High school diploma & $\begin{array}{l}-11.43 \\
(22.899)\end{array}$ & $\begin{array}{l}7.35 \\
(20.043)\end{array}$ & $\begin{array}{l}-18.78 \\
(19.301)\end{array}$ & $\begin{array}{l}-2.66 \\
(9.107)\end{array}$ & $\begin{array}{l}-6.45 \\
(7.625)\end{array}$ & $\begin{array}{l}3.79 \\
(5.147)\end{array}$ \\
\hline Some college & $\begin{array}{l}-57.63 * \\
(23.401)\end{array}$ & $\begin{array}{l}-19.47 \\
(20.792)\end{array}$ & $\begin{array}{l}-38.15^{*} \\
(18.718)\end{array}$ & $\begin{array}{l}3.24 \\
(10.065)\end{array}$ & $\begin{array}{l}-1.65 \\
(8.352)\end{array}$ & $\begin{array}{l}4.89 \\
(5.247)\end{array}$ \\
\hline College graduate & $\begin{array}{l}-37.42 \\
(23.596)\end{array}$ & $\begin{array}{l}-17.61 \\
(20.619)\end{array}$ & $\begin{array}{l}-19.81 \\
(20.476)\end{array}$ & $\begin{array}{l}9.37 \\
(9.396)\end{array}$ & $\begin{array}{l}-5.17 \\
(7.631)\end{array}$ & $\begin{array}{l}14.53 * * \\
(5.552)\end{array}$ \\
\hline Professional occupation & $\begin{array}{l}-9.58 \\
(12.762)\end{array}$ & $\begin{array}{l}-3.08 \\
(10.441)\end{array}$ & $\begin{array}{l}-6.50 \\
(8.971)\end{array}$ & $\begin{array}{l}-5.47 \\
(5.422)\end{array}$ & $\begin{array}{l}1.22 \\
(3.492)\end{array}$ & $\begin{array}{l}-6.69 \\
(3.896)\end{array}$ \\
\hline \multicolumn{7}{|c|}{ Spouse's employment $($ ref. $=$ non-employed $)$} \\
\hline Part-time & $\begin{array}{l}-1.31 \\
(16.362)\end{array}$ & $\begin{array}{l}-34.76^{* *} \\
(13.326)\end{array}$ & $\begin{array}{l}33.45 * * \\
(10.962)\end{array}$ & $\begin{array}{l}13.23^{*} \\
(6.425)\end{array}$ & $\begin{array}{l}-0.06 \\
(4.273)\end{array}$ & $\begin{array}{l}13.29 * * \\
(5.115)\end{array}$ \\
\hline Full-time & $\begin{array}{l}-19.03 \\
(11.937)\end{array}$ & $\begin{array}{l}-44.33 * * * \\
(10.972)\end{array}$ & $\begin{array}{l}25.31 * * \\
(7.885)\end{array}$ & $\begin{array}{l}13.86^{* * *} \\
(4.718)\end{array}$ & $\begin{array}{l}0.71 \\
(3.577)\end{array}$ & $\begin{array}{l}13.15 * * * \\
(3.189)\end{array}$ \\
\hline Worked on diary day & $\begin{array}{l}-161.56^{* * * *} \\
(17.922)\end{array}$ & $\begin{array}{l}-135.71 * * * \\
(16.790)\end{array}$ & $\begin{array}{l}-25.85^{*} \\
(11.215)\end{array}$ & $\begin{array}{l}-18.43 * * \\
(7.032)\end{array}$ & $\begin{array}{l}-16.11 * * * \\
(4.384)\end{array}$ & $\begin{array}{l}-2.32 \\
(5.533)\end{array}$ \\
\hline \multicolumn{7}{|c|}{ Family income (ref. $=<\$ 25,000)$} \\
\hline$\$ 25 \mathrm{k}$ to $\$ 50 \mathrm{k}$ & $\begin{array}{l}-66.44 * \\
(27.170)\end{array}$ & $\begin{array}{l}-75.85 * * \\
(25.715)\end{array}$ & $\begin{array}{l}9.41 \\
(18.348)\end{array}$ & $\begin{array}{l}7.72 \\
(10.292)\end{array}$ & $\begin{array}{l}-6.67 \\
(8.977)\end{array}$ & $\begin{array}{l}14.39 * * \\
(4.734)\end{array}$ \\
\hline$\$ 50 \mathrm{k}$ to $\$ 75 \mathrm{k}$ & $-64.05^{*}$ & $-68.65^{*}$ & 4.60 & 7.97 & -2.38 & $10.36^{*}$ \\
\hline
\end{tabular}




\begin{tabular}{|c|c|c|c|c|c|c|}
\hline \multicolumn{7}{|c|}{ Total Time } \\
\hline & All & Family & Solo & All & Family & Solo \\
\hline & $(28.166)$ & $(26.997)$ & $(18.647)$ & $(10.626)$ & $(9.331)$ & $(5.151)$ \\
\hline$\$ 75 \mathrm{k}$ to $\$ 100 \mathrm{k}$ & $\begin{array}{l}-55.31 \\
(30.748)\end{array}$ & $\begin{array}{l}-71.16^{*} \\
(28.238)\end{array}$ & $\begin{array}{l}15.85 \\
(19.908)\end{array}$ & $\begin{array}{l}10.25 \\
(10.867)\end{array}$ & $\begin{array}{l}-4.38 \\
(9.388)\end{array}$ & $\begin{array}{l}14.63 * \\
(5.699)\end{array}$ \\
\hline$\$ 100 \mathrm{k}+$ & $\begin{array}{l}-28.79 \\
(29.433)\end{array}$ & $\begin{array}{l}-58.26^{*} \\
(28.531)\end{array}$ & $\begin{array}{l}29.48 \\
(19.298)\end{array}$ & $\begin{array}{l}29.02 * \\
(11.685)\end{array}$ & $\begin{array}{l}1.96 \\
(9.713)\end{array}$ & $\begin{array}{l}27.06 * * * \\
(7.027)\end{array}$ \\
\hline \multicolumn{7}{|l|}{ Race (ref. = white) } \\
\hline Black & $\begin{array}{l}-23.54 \\
(20.363)\end{array}$ & $\begin{array}{l}-17.26 \\
(19.032)\end{array}$ & $\begin{array}{l}-6.28 \\
(13.619)\end{array}$ & $\begin{array}{l}-7.61 \\
(7.010)\end{array}$ & $\begin{array}{l}-10.37 * * \\
(3.575)\end{array}$ & $\begin{array}{l}2.76 \\
(6.292)\end{array}$ \\
\hline Latin $x$ & $\begin{array}{l}-3.59 \\
(18.493)\end{array}$ & $\begin{array}{l}7.34 \\
(14.630)\end{array}$ & $\begin{array}{l}-10.93 \\
(12.733)\end{array}$ & $\begin{array}{l}-6.97 \\
(7.682)\end{array}$ & $\begin{array}{l}-1.03 \\
(5.679)\end{array}$ & $\begin{array}{l}-5.94 \\
(5.050)\end{array}$ \\
\hline Other & $\begin{array}{l}18.95 \\
(15.400)\end{array}$ & $\begin{array}{l}36.68 * \\
(14.732)\end{array}$ & $\begin{array}{l}-17.73 \\
(10.090)\end{array}$ & $\begin{array}{l}-4.19 \\
(6.037)\end{array}$ & $\begin{array}{l}2.49 \\
(4.317)\end{array}$ & $\begin{array}{l}-6.68 \\
(4.669)\end{array}$ \\
\hline Age & $\begin{array}{l}-0.24 \\
(0.762)\end{array}$ & $\begin{array}{l}-0.94 \\
(0.678)\end{array}$ & $\begin{array}{l}0.70 \\
(0.458)\end{array}$ & $\begin{array}{l}-0.86 * * \\
(0.263)\end{array}$ & $\begin{array}{l}-0.76 * * * \\
(0.188)\end{array}$ & $\begin{array}{l}-0.10 \\
(0.195)\end{array}$ \\
\hline Cohabiting & $\begin{array}{l}-46.81 * \\
(20.634)\end{array}$ & $\begin{array}{l}-38.87 \\
(19.902)\end{array}$ & $\begin{array}{l}-7.95 \\
(14.047)\end{array}$ & $\begin{array}{l}-19.54 * \\
(7.955)\end{array}$ & $\begin{array}{l}-10.54 \\
(6.268)\end{array}$ & $\begin{array}{l}-9.01 \\
(6.381)\end{array}$ \\
\hline \multicolumn{7}{|c|}{ Age of youngest child (ref. $=0-5$ years old) } \\
\hline 6-12 years old & $\begin{array}{l}-28.31 * \\
(12.605)\end{array}$ & $\begin{array}{l}-26.45^{*} \\
(11.199)\end{array}$ & $\begin{array}{l}-1.87 \\
(8.469)\end{array}$ & $\begin{array}{l}-38.06 * * * \\
(5.378)\end{array}$ & $\begin{array}{l}-18.42 * * * \\
(3.790)\end{array}$ & $\begin{array}{l}-19.64 * * * \\
(3.936)\end{array}$ \\
\hline $13-17$ years old & $\begin{array}{l}-128.63 * * * \\
(17.481)\end{array}$ & $\begin{array}{l}-95.23 * * * \\
(15.377)\end{array}$ & $\begin{array}{l}-33.40 * * \\
(10.661)\end{array}$ & $\begin{array}{l}-59.36 * * * \\
(6.638)\end{array}$ & $\begin{array}{l}-29.56 * * * \\
(3.856)\end{array}$ & $\begin{array}{l}-29.81 * * * \\
(5.401)\end{array}$ \\
\hline Number of own HH kids under 18 & $\begin{array}{l}14.46^{*} \\
(6.141)\end{array}$ & $\begin{array}{l}-3.42 \\
(5.014)\end{array}$ & $\begin{array}{l}17.88 * * * \\
(4.311)\end{array}$ & $\begin{array}{l}-0.05 \\
(2.649)\end{array}$ & $\begin{array}{l}-2.11 \\
(1.542)\end{array}$ & $\begin{array}{l}2.07 \\
(2.113)\end{array}$ \\
\hline Weekend diary & $\begin{array}{l}146.16^{* * * *} \\
(16.314)\end{array}$ & $\begin{array}{l}112.18 * * * \\
(15.102)\end{array}$ & $\begin{array}{l}33.97 * * * \\
(10.200)\end{array}$ & $\begin{array}{l}8.98 \\
(6.541)\end{array}$ & $\begin{array}{l}2.33 \\
(3.730)\end{array}$ & $\begin{array}{l}6.65 \\
(5.479)\end{array}$ \\
\hline Holiday diary & $\begin{array}{l}128.28 * * * \\
(38.085)\end{array}$ & $\begin{array}{l}111.34 * \\
(52.926)\end{array}$ & $\begin{array}{l}16.93 \\
(36.246)\end{array}$ & $\begin{array}{l}-24.85 \\
(23.123)\end{array}$ & $\begin{array}{l}-8.49 \\
(22.647)\end{array}$ & $\begin{array}{l}-16.35 \\
(8.948)\end{array}$ \\
\hline Summer diary & $\begin{array}{l}2.74 \\
(13.442)\end{array}$ & $\begin{array}{l}0.04 \\
(12.132)\end{array}$ & $\begin{array}{l}2.70 \\
(8.727)\end{array}$ & $\begin{array}{l}-4.59 \\
(5.306)\end{array}$ & $\begin{array}{l}-5.98 \\
(3.412)\end{array}$ & $\begin{array}{l}1.38 \\
(4.469)\end{array}$ \\
\hline Access to flexplace & $\begin{array}{l}22.39 \\
(17.600)\end{array}$ & $\begin{array}{l}31.85^{*} \\
(14.491)\end{array}$ & $\begin{array}{l}-9.46 \\
(11.374)\end{array}$ & $\begin{array}{l}0.44 \\
(5.149)\end{array}$ & $\begin{array}{l}4.45 \\
(3.766)\end{array}$ & $\begin{array}{l}-4.01 \\
(3.843)\end{array}$ \\
\hline Constant & $\begin{array}{l}490.06 * * * \\
(60.995)\end{array}$ & $\begin{array}{l}390.87 * * * \\
(52.912)\end{array}$ & $\begin{array}{l}99.19 \\
(54.413)\end{array}$ & $\begin{array}{l}101.43 * * * \\
(20.257)\end{array}$ & $\begin{array}{l}80.81 * * * \\
(16.114)\end{array}$ & $\begin{array}{l}20.61 \\
(11.943)\end{array}$ \\
\hline
\end{tabular}

Note: ATUS 2017-2018 Leave Module. Total $N=1,882$. Analyses are weighted with population and replicate weights. 
Table A.5: OLS regression estimates for frequency of flexplace use and fathers' time with children

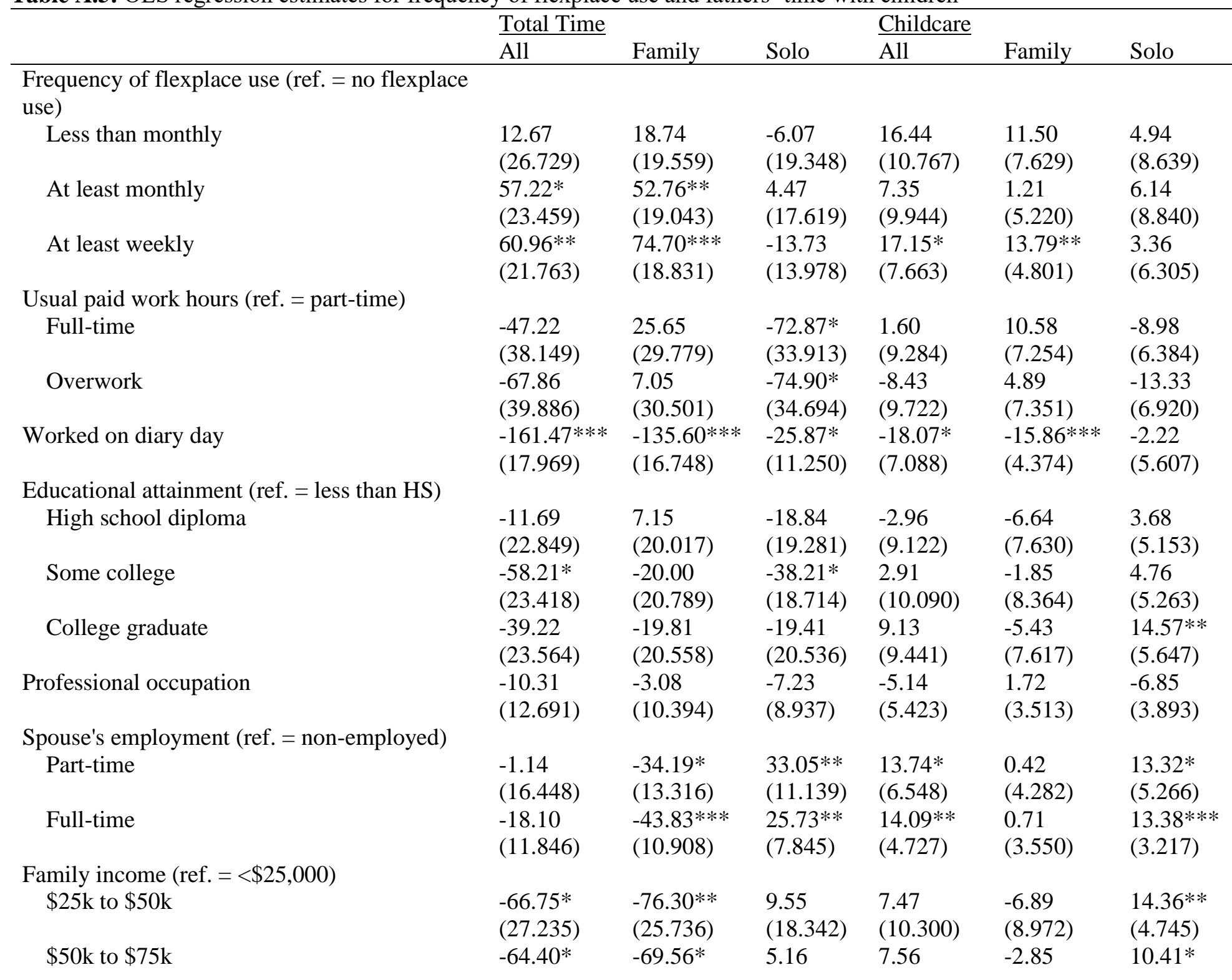




\begin{tabular}{|c|c|c|c|c|c|c|}
\hline & \multicolumn{3}{|l|}{ Total Time } & \multicolumn{3}{|l|}{ Childcare } \\
\hline & All & Family & Solo & All & Family & Solo \\
\hline & $(28.212)$ & $(26.985)$ & $(18.640)$ & $(10.634)$ & $(9.315)$ & $(5.162)$ \\
\hline$\$ 75 \mathrm{k}$ to $\$ 100 \mathrm{k}$ & $\begin{array}{l}-55.42 \\
(30.824)\end{array}$ & $\begin{array}{l}-71.51 * \\
(28.258)\end{array}$ & $\begin{array}{l}16.09 \\
(19.914)\end{array}$ & $\begin{array}{l}10.29 \\
(10.863)\end{array}$ & $\begin{array}{l}-4.43 \\
(9.387)\end{array}$ & $\begin{array}{l}14.72 * * \\
(5.690)\end{array}$ \\
\hline$\$ 100 \mathrm{k}+$ & $\begin{array}{l}-28.75 \\
(29.485)\end{array}$ & $\begin{array}{l}-58.07 * \\
(28.545)\end{array}$ & $\begin{array}{l}29.32 \\
(19.283)\end{array}$ & $\begin{array}{l}29.00 * \\
(11.702)\end{array}$ & $\begin{array}{l}1.99 \\
(9.708)\end{array}$ & $\begin{array}{l}27.01 * * * \\
(7.046)\end{array}$ \\
\hline \multicolumn{7}{|l|}{ Race (ref. = white) } \\
\hline Black & $\begin{array}{l}-25.08 \\
(20.409)\end{array}$ & $\begin{array}{l}-18.62 \\
(18.922)\end{array}$ & $\begin{array}{l}-6.45 \\
(13.547)\end{array}$ & $\begin{array}{l}-7.46 \\
(7.055)\end{array}$ & $\begin{array}{l}-10.19 * * \\
(3.511)\end{array}$ & $\begin{array}{l}2.73 \\
(6.247)\end{array}$ \\
\hline Latin $x$ & $\begin{array}{l}-4.60 \\
(18.602)\end{array}$ & $\begin{array}{l}6.46 \\
(14.637)\end{array}$ & $\begin{array}{l}-11.06 \\
(12.778)\end{array}$ & $\begin{array}{l}-7.09 \\
(7.697)\end{array}$ & $\begin{array}{l}-1.06 \\
(5.689)\end{array}$ & $\begin{array}{l}-6.03 \\
(5.094)\end{array}$ \\
\hline Other & $\begin{array}{l}19.25 \\
(15.157)\end{array}$ & $\begin{array}{l}37.38 * \\
(14.681)\end{array}$ & $\begin{array}{l}-18.13 \\
(9.883)\end{array}$ & $\begin{array}{l}-3.63 \\
(5.948)\end{array}$ & $\begin{array}{l}3.02 \\
(4.278)\end{array}$ & $\begin{array}{l}-6.65 \\
(4.579)\end{array}$ \\
\hline Age & $\begin{array}{l}-0.29 \\
(0.765)\end{array}$ & $\begin{array}{l}-1.00 \\
(0.680)\end{array}$ & $\begin{array}{l}0.71 \\
(0.456)\end{array}$ & $\begin{array}{l}-0.86 * * \\
(0.262)\end{array}$ & $\begin{array}{l}-0.77 * * * \\
(0.188)\end{array}$ & $\begin{array}{l}-0.09 \\
(0.194)\end{array}$ \\
\hline Cohabiting & $\begin{array}{l}-47.53 * \\
(20.635)\end{array}$ & $\begin{array}{l}-39.95 * \\
(19.882)\end{array}$ & $\begin{array}{l}-7.58 \\
(14.029)\end{array}$ & $\begin{array}{l}-19.64 * \\
(7.957)\end{array}$ & $\begin{array}{l}-10.70 \\
(6.273)\end{array}$ & $\begin{array}{l}-8.94 \\
(6.348)\end{array}$ \\
\hline \multicolumn{7}{|c|}{ Age of youngest child (ref. $=0-5$ years old) } \\
\hline 6-12 years old & $\begin{array}{l}-28.26^{*} \\
(12.514)\end{array}$ & $\begin{array}{l}-26.01 * \\
(11.138)\end{array}$ & $\begin{array}{l}-2.26 \\
(8.422)\end{array}$ & $\begin{array}{l}-38.28 * * * \\
(5.367)\end{array}$ & $\begin{array}{l}-18.44 * * * \\
(3.780)\end{array}$ & $\begin{array}{l}-19.84 * * * \\
(3.908)\end{array}$ \\
\hline $13-17$ years old & $\begin{array}{l}-129.87 * * * \\
(17.527)\end{array}$ & $\begin{array}{l}-95.83 * * * \\
(15.489)\end{array}$ & $\begin{array}{l}-34.05^{* *} \\
(10.526)\end{array}$ & $\begin{array}{l}-60.07 * * * \\
(6.532)\end{array}$ & $\begin{array}{l}-29.80 * * * \\
(3.853)\end{array}$ & $\begin{array}{l}-30.26 * * * \\
(5.261)\end{array}$ \\
\hline Number of own HH kids under 18 & $\begin{array}{l}14.82 * \\
(6.094)\end{array}$ & $\begin{array}{l}-3.04 \\
(5.018)\end{array}$ & $\begin{array}{l}17.86^{* * * *} \\
(4.320)\end{array}$ & $\begin{array}{l}-0.15 \\
(2.668)\end{array}$ & $\begin{array}{l}-2.18 \\
(1.555)\end{array}$ & $\begin{array}{l}2.03 \\
(2.125)\end{array}$ \\
\hline Weekend diary & $\begin{array}{l}145.48 * * * \\
(16.368)\end{array}$ & $\begin{array}{l}111.66 * * * \\
(15.094)\end{array}$ & $\begin{array}{l}33.81 * * \\
(10.293)\end{array}$ & $\begin{array}{l}9.25 \\
(6.594)\end{array}$ & $\begin{array}{l}2.58 \\
(3.732)\end{array}$ & $\begin{array}{l}6.67 \\
(5.555)\end{array}$ \\
\hline Holiday diary & $\begin{array}{l}129.46 * * * \\
(38.003)\end{array}$ & $\begin{array}{l}113.78 * \\
(52.333)\end{array}$ & $\begin{array}{l}15.67 \\
(35.967)\end{array}$ & $\begin{array}{l}-23.77 \\
(23.455)\end{array}$ & $\begin{array}{l}-7.35 \\
(22.692)\end{array}$ & $\begin{array}{l}-16.42 \\
(9.271)\end{array}$ \\
\hline Summer diary & $\begin{array}{l}2.74 \\
(13.437)\end{array}$ & $\begin{array}{l}0.26 \\
(12.110)\end{array}$ & $\begin{array}{l}2.48 \\
(8.715)\end{array}$ & $\begin{array}{l}-4.70 \\
(5.311)\end{array}$ & $\begin{array}{l}-5.98 \\
(3.409)\end{array}$ & $\begin{array}{l}1.28 \\
(4.466)\end{array}$ \\
\hline Access to flexplace & $\begin{array}{l}24.77 \\
(17.460)\end{array}$ & $\begin{array}{l}34.03 * \\
(14.321)\end{array}$ & $\begin{array}{l}-9.26 \\
(11.319)\end{array}$ & $\begin{array}{l}0.15 \\
(5.140)\end{array}$ & $\begin{array}{l}4.17 \\
(3.758)\end{array}$ & $\begin{array}{l}-4.01 \\
(3.837)\end{array}$ \\
\hline Constant & $\begin{array}{l}491.28 * * * \\
(61.004)\end{array}$ & $\begin{array}{l}391.98 * * * \\
(53.016)\end{array}$ & $\begin{array}{l}99.30 \\
(54.346)\end{array}$ & $\begin{array}{l}101.61 * * * \\
(20.252)\end{array}$ & $\begin{array}{l}80.90 * * * \\
(16.107)\end{array}$ & $\begin{array}{l}20.72 \\
(11.906)\end{array}$ \\
\hline
\end{tabular}

Note: ATUS 2017-2018 Leave Module. Total $N=1,882$. Analyses are weighted with population and replicate weights. 